\title{
NEWLY RESOLVED RELATIONSHIPS IN AN EARLY LAND PLANT LINEAGE: BRYOPHYTA ClASS SPHAGNOPSIDA (PEAT MOSSES) ${ }^{1}$
}

\author{
A. Jonathan Shaw ${ }^{2,11}$, Cymon J. Cox ${ }^{3}$, William R. Buck ${ }^{4}$, Nicolas Devos 5 , Alex M. \\ Buchanan $^{6}$, Lynette Cave ${ }^{6}$, Rodney Seppelt ${ }^{7}$, Blanka Shaw $^{2}$, Juan Larraín ${ }^{8}$, \\ Richard Andrus ${ }^{9}$, Johann Greilhuber $^{10}$, AND Eva M. Temsch ${ }^{10}$
}

${ }^{2}$ Duke University, Department of Biology, Durham, North Carolina 27708 USA; ${ }^{3}$ Centro de Ciências do Mar, Universidade do Algarve, Campus de Gambelas, 8005-139 Faro, Portugal; ${ }^{4}$ Institute of Systematic Botany, The New York Botanical Garden, Bronx, New York 10458 USA; ${ }^{5}$ Institute of Botany, University of Liège, B22 Sart Tilman, B-4000 Liège, Belgium; ${ }^{6}$ Tasmanian Herbarium, Private Bag 4, Hobart, Tasmania 7001, Australia; ${ }^{7}$ Australian Antarctic Division, Channel Highway, Kingston, Tasmania 7050, Australia; ${ }^{8}$ Departamento de Botánica, Universidad de Concepción, Casilla 160-C, Concepción, Chile;

${ }^{9}$ Departments of Environmental Studies and Biological Sciences, Binghamton University, Vestal Parkway East, P.O. Box 6000, Binghamton, New York 13902 USA; and ${ }^{10}$ Department of Systematic and Evolutionary Botany, Faculty of Life Sciences, University of Vienna, Rennweg 14, A 1030 Vienna, Austria

- Premise of the study: The Sphagnopsida, an early-diverging lineage of mosses (phylum Bryophyta), are morphologically and ecologically unique and have profound impacts on global climate. The Sphagnopsida are currently classified in two genera, Sphagnum (peat mosses) with some 350-500 species and Ambuchanania with one species. An analysis of phylogenetic relationships among species and genera in the Sphagnopsida were conducted to resolve major lineages and relationships among species within the Sphagnopsida.

- Methods: Phylogenetic analyses of nucleotide sequences from the nuclear, plastid, and mitochondrial genomes (11704 nucleotides total) were conducted and analyzed using maximum likelihood and Bayesian inference employing seven different substitution models of varying complexity.

- Key results: Phylogenetic analyses resolved three lineages within the Sphagnopsida: (1) Sphagnum sericeum, (2) S. inretortum plus Ambuchanania leucobryoides, and (3) all remaining species of Sphagnum. Sister group relationships among these three clades could not be resolved, but the phylogenetic results indicate that the highly divergent morphology of A. leucobryoides is derived within the Sphagnopsida rather than plesiomorphic. A new classification is proposed for class Sphagnopsida, with one order (Sphagnales), three families, and four genera.

- Conclusions: The Sphagnopsida are an old lineage within the phylum Bryophyta, but the extant species of Sphagnum represent a relatively recent radiation. It is likely that additional species critical to understanding the evolution of peat mosses await discovery, especially in the southern hemisphere.

Key words: Ambuchanania; bryophyte phylogeny; land plant phylogeny; peat mosses; Sphagnopsida; Sphagnum.

Phylogenetic analyses of genome structure and nucleotide sequences from mitochondrial, plastid, and nuclear genes have corroborated the view held by botanists for over a century that the bryophyte groups (mosses, liverworts, hornworts) comprise early-diverging land plant lineages that originated before the appearance of vascular plants (Haeckel, 1876; Campbell, 1895; Bower, 1935; Kenrick and Crane, 1997; Shaw and Renzaglia, 2004). Early cladistic analyses based on morphological characters (Mishler and Churchill, 1984) showed that the three bryophyte groups, classified by most botanists of the time as a single phylum because of their similar gametophyte-dominant life cycles, more likely represent a paraphyletic grade that diverged before the emergence of the vascular plants. In fact, Haeckel's

\footnotetext{
1 Manuscript received 10 February 2010; revision accepted 16 June 2010. This research was supported NSF grant no. DEB-0918998 to A.J.S. and B.S. The authors thank Sandra Boles, Duke University, for technical assistance and Robert Krisai, University of Salzburg, for providing a herbarium specimen of Sphagnum girgensohnii from the Lesachtal, Lungau, Salzburg for genome size analysis.

11 Author for correspondence (e-mail: shaw@duke.edu)
}

doi:10.3732/ajb.1000055
(1876) tree similarly shows mosses and liverworts as a paraphyletic grade basal to the vascular plants. Recent data sets appear to favor the hypothesis that liverworts (phylum Marchantiophyta) comprise the earliest-diverging lineage, followed by the mosses (Bryophyta) and hornworts (Anthocerophyta) (Qiu et al., 1998; Nickrent et al., 2000; Shaw and Renzaglia, 2004). However, the most data-rich studies to date, based on chloroplast or mitochondrial organellar proteins, like analyses based on sperm cell morphology (Garbary et al., 1993), identify a clade uniting liverworts and mosses, and additional data are still needed before we can consider the branching order of early land plant lineages to be finally resolved (Nishiyama et al., 2004; Rodríguez-Ezpeleta et al., 2007; Terasawa et al., 2007; but see also Qiu, et al., 2006).

Notwithstanding that much remains to do, great progress has been made toward resolving phylogenetic relationships within the mosses (phylum Bryophyta s.s.) (e.g., Cox and Hedderson, 1999; Cox et al., 2000; Newton et al., 2000; Goffinet et al., 2001; Stech and Frey, 2008; Goffinet et al., 2009; Wahrmund et al., 2010). Major clades resolved by molecular data to a large extent mirror previous classifications based on morphology (e.g., Fleischer, 1923; Brotherus, 1924-1925; Vitt, 1984). A simple classification for Bryophyta that represents phylogenetic relationships divides the phylum into five classes: Bryopsida, 
Takakiopsida, Andreaeopsida, Andreaeobryopsida, and Sphagnopsida (Stech and Frey, 2008; Goffinet et al., 2009). The classes of phylum Bryophyta differ in basic developmental features including embryological origins of the sporogenous and columellar tissue of sporophytes, dehiscence of sporangia, and morphology of the gametangia and sperm cells (Cavers, 1911; Schofield, 1985; Crum, 2001b; Garbary et al., 1993; Vanderpoorten and Goffinet, 2009). The class Bryopsida includes most familiar mosses, with some 10000 species (Crosby et al., 2000). The Andreaeopsida and Sphagnopsida each include about 350-500 species, the Takakiopsida two, and Andreaeobryopsida one.

The Sphagnopsida comprise a morphologically distinctive group, and some have argued that they should be classified in a phylum separate from other mosses (Steere, 1958; Crum, 2001b). Phylogenetic analyses based on morphological and molecular characters, however, have shown that the Sphagnopsida are part of a monophyletic Bryophyta (i.e., mosses: Garbary et al., 1993; Hedderson et al., 1996; Beckert et al., 1999). Within the Bryophyta, plants of Sphagnopsida are distinguished from other mosses by numerous morphological and developmental features. Gametophyte features include thalloid protonemata (shared with Andreaeopsida and a few early-diverging members of the Bryopsida), dimorphic leaf cells of mature leaves, and typical absence of rhizoids attaching mature plants to their substrates. Enlarged, hyaline leaf cells, dead at maturity and with various reinforcing cell wall fibrils and pores, are enclosed within a network of much narrower chlorophyllose cells. This pattern is not found in any other moss, although loosely analogous cell dimorphism occurs in scattered species of the class Bryopsida. Ontogeny of the chlorophyllose and hyaline cells during leaf development in Sphagnum is unique (e.g., Holcombe, 1984; Butterfass, 1992). Asymmetric cell divisions during leaf ontogeny give rise to groups of three cells from a single initial (a so-called triad), one hyaline and empty at maturity and two chlorophyllose cells (Butterfass, 1992). At maturity, each hyaline cell is surrounded by five or more narrow hyaline cells, two of them derived from the same triad and others related by cell lineage to adjacent hyaline cells.

The Sphagnopsida also differ from other mosses in that elongation of gametophyte stems involves subapical meristematic activity in fully differentiated cells derived from the apical cell itself (Ligrone and Duckett, 1998). The sperm cells of Sphagnum are characterized by at least five apomorphic character states pertaining to the flagellar apparatus, and antheridia of Sphagnum differ from those in other mosses in lacking opercular cells (Garbary et al., 1993). The gametophyte-sporophyte junction in Sphagnum lacks placental wall ingrowths, in contrast to those of other mosses (Ligrone et al., 1993).

The sporophyte generation of Sphagnopsida is also highly differentiated. The sporophyte lacks a seta (stalk) and is instead raised on a pseudopodium of (maternal) gametophyte origin, a feature shared with Andreaeopsida but not Andreaeobryopsida, Bryopsida, or Takakiopsida. The sporogenous tissue within the sporangium of Sphagnopsida develops from embryonic amphithecial rather than endothecial tissue and overarches a massive columella (derived from the endothecium). The columella is much more slender in other mosses and the sporogenous tissue is derived from the outer layer(s) of endothecium, rather than the amphithecium. Endothecium and amphithecium differentiate at a very early stage of sporophyte development, and the difference between Sphagnopsida and other mosses is viewed as fundamental. The sporangia (capsules) of Sphagnopsida dehisce by an apical operculum, as in Bryopsida (in contrast to the vertical or spiral suture lines in Andreaeopsida/Andreaeobryopsida and Takakiopsida, respectively), but unlike most true mosses (Bryopsida), Sphagnopsida have no peristomes and the capsules open via a unique "pop-gun" mechanism wherein the operculum detaches explosively as the capsule shrinks in diameter (Duckett et al., 2009).

The Sphagnopsida are currently classified in two orders (Ambuchananiales, Sphagnales), each with a single family and genus (Ambuchananiaceae, Ambuchanania; Sphagnaceae, Sphagnum) (Seppelt, 2000; Crum, 2001b). Ambuchanania leucobryoides (as Sphagnum) was described (Yamaguchi et al., 1990) from a single collection made in Tasmania in 1987. It was first classified in a new section of Sphagnum but later (Crum and Seppelt, 1999) moved to a newly erected family and order.

Ambuchanania has hyaline and chlorophyllose (i.e., dimorphic) leaf cells like Sphagnum, and some of the hyaline cells are ornamented with cell wall fibrils and pores. Although the morphological details of the leaf areolation differ from any Sphagnum species, these features clearly connect Ambuchanania to the latter genus. Also like Sphagnum, Ambuchanania gametophytes lack rhizoids at maturity. Gametophyte plants are relatively small and lack fasciculate branching, an unusual but not unique trait in Sphagnum. Ambuchanania has bisexual gametophytes like some species of Sphagnum, but the antheridia are oblong-elongate, unlike the spherical antheridia of Sphagnum. The antheridia of Ambuchanania occur in naked clusters below the archegonia, rather than on well-differentiated branches as in Sphagnum, and the archegonia are terminal on stems rather than on short lateral branches as in Sphagnum.

The sporophyte of Ambuchanania is similar to those in Sphagnum and is raised on a terminal pseudopodium of gametophytic origin. Like Sphagnum, the capsule wall of Ambuchanania has abundant pseudostomata, similar in structure to stomata but apparently nonfunctional (Crum, 2001b; Duckett et al., 2009).

It is because of these many structural features that distinguish Ambuchanania from Sphagnum that the genus has been classified in a separate family and order from Sphagnum. This interpretation is supported by molecular phylogenetic data presented by Shaw (2000) and greatly expanded here. The interpretation of morphological evolution in the Sphagnopsida and the classification for the group are, however, complicated by new information (below) that several species having more or less typical morphology for Sphagnum are more closely related to Ambuchanania than they are to Sphagnum s.s.

In this paper, we present new molecular data on relationships in the Sphagnopsida, illustrate selected morphological characters of Ambuchanania and related species, and propose a new classification for the class Sphagnopsida.

\section{MATERIALS AND METHODS}

Taxon sampling and data acquisition-Extraction, amplification, and sequencing followed protocols described in Shaw et al. (2003). The following genes were sequenced: photosystem II (PSII) reaction center protein D1 ( $p s b A$ ), photosystem II (PSII) reaction center protein T ( $p s b T-H)$, ribulose-bisphosphate carboxylase gene $(r b c L)$, RNA polymerase subunit beta ( $r p o C 1)$, ribosomal small protein 4 (rps4), tRNA(Gly) (UCC) $(\operatorname{trn} G)$, and the $\operatorname{trnL}$ (UAA) 59 exon$\operatorname{trnF}$ (GAA) region (trnL) from the plastid genome; introns within NADH protein-coding subunits 5 and 7 ( $\operatorname{cad} 5$, nad7, respectively) from the mitochondrial genome; and 18S ribosomal RNA (18S) and 26S ribosomal RNA (26S) from the nuclear genome. The nuclear ribosomal internal transcribed spacer region (ITS) was sequenced in selected species and inferences from these data are briefly discussed, but they were not included in the formal phylogenetic analyses. Primer sequences for amplifying and sequencing the loci were provided in Shaw et al. (2003), with the exception of $r p o C 1$. For this locus, we used primers 
described in the Royal Botanic Gardens, Kew, web page: DNA Barcoding, phase 2 protocols (http://www.kew.org/barcoding/protocols.html).

Two multilocus molecular data sets were constructed, one with a diverse range of 56 taxa drawn from across the Bryophyta plus four species of Marchantiophyta as outgroups (60 taxa and eight loci), and a second data set with a restricted number of taxa but more data (nine taxa and 11 loci). The 60-taxon data set includes 26 species of class Bryopsida, the "true" (peristomate) mosses. These represent all major clades of Bryopsida; the data set was used by Cox et al. (2004) to resolve backbone relationships among mosses. As in that previous analysis (Cox et al., 2004), our data set also includes (in addition to Bryopsida) one sample each of Takakia (Takakiopsida), Andreaea (Andreaeopsida), and Andreaeobryum (Andreaeobryopsida). To this data set we added 24 species of Sphagnum representing all the commonly recognized infrageneric groups (subgenera or sections, depending on the author; e.g., Warnstorf, 1911; Crum, 1984), plus two species of uncertain relationship within Sphagnum (i.e., S. sericeum Müll. Hal., S. inretortum H. A. Crum; Shaw et al., 2003 [the latter as S. lapazense]), and a sample of Ambuchanania leucobryoides recently collected from Tasmania (Johnson et al., 2008).

In an attempt to evaluate the possibility that Ambuchanania leucobryoides and $S$. inretortum are sister species, a hypothesis developed from analyses of the 60-taxon data set, we removed the liverwort outgroups and all exemplars of class Bryopsida, represented Sphagnum s.s. (which is unambiguously supported as monophyletic) by two divergent species, and also included Ambuchanania, S. inretortum and S. sericeum, which were resolved outside Sphagnum s.s. in the 60-taxon analysis (as well as by analyses in Shaw et al., 2003). Exemplars of Andreaea and Takakia were included as outgroups to establish phylogenetic polarity within the Sphagnopsida.

One of the critical taxa in this study, S. inretortum, is represented by two population samples in our analyses. One is the type specimen of S. lapazense H. A. Crum (Bolivia, sampled with permission of H. Crum), and the second is from a morphologically similar population (Chile) discovered while this work was in progress. When this manuscript was almost completed, we realized (based on morphological comparisons) that the type specimen of S. inretortum (Bolivia) also appears to be conspecific with plants from these other populations. The type of S. inretortum was collected in 1981 and attempts to amplify DNA from it (with permission of H. Crum) have been unsuccessful. On the basis of morphological similarities all three specimens are referred to here as S. inretortum, which is an earlier name than S. lapazense.

Reduced sampling relative to the 60-taxon data set, especially the removal of the liverwort outgroups and species of bryopsid mosses, permitted more of the data to be included in analyses because alignment of more variable regions could be accomplished without unacceptable ambiguity. In addition, sequences from three additional loci were added to the concatenated data: nad5 from the mitochondrial genome and $r p o C l$ and $p s b T$ from the plastid genome.

The 60-taxon, 8-locus data set was used in a companion paper (Shaw et al., 2010) to the present one, describing the timeframe of diversification in Sphagnopsida, and GenBank accession numbers were reported in that paper. For the sake of completeness, all GenBank numbers, including those previously published as well as those newly generated for this paper, are provided in Appendix 1. The two data matrices used for these analyses are available in TreeBase (http:// treebase.org, accession number TB2:10581).

Phylogenetic analyses: 60-taxon, eight-locus data set-Single-locus data sets of SSU, LSU, rbcL, rps4, psbA, $\operatorname{trn} G, \operatorname{trn} L$, and $n a d 7$ sequences were aligned using the software MUSCLE (vers. 3.7; Edgar, 2004) with default options. Alignments were adjusted by eye using the program SEA VIEW (vers. 4; Galtier et al., 1996); regions of ambiguous alignment were identified and excluded from further analysis. Taxa with identical sequences after exclusion of ambiguous regions were reduced to a single taxon representative before the analyses were conducted to reduce the computational effort required-the excluded taxa were later restored to the trees when represented graphically. Optimal substitution models were selected to maximize the Akaike information criterion (AIC) statistic for each locus using the software MrModeltest (vers. 2.3; Nylander, 2004) in conjunction with the program PAUP* (vers. 4.0b10; Swofford, 1998).

Maximum likelihood (ML) bootstrap analyses were conducted (300 replicates) on each individual gene using the program RAxML (vers. 7.0.4; Stamatakis, 2006; Stamatakis, et al., 2008). All genes were analyzed using the optimal models, except $\operatorname{trn} L$ whose optimal model Hasagawa-Kishino-Yano (HKY) is not implemented in RAxML. For trnL, the best model identified by AIC and implemented in RAxML was used; i.e., the general time-reversible model (GTR).

Each gene data set was analyzed with the Bayesian Markov chain Monte Carlo (MCMC) inference software p4 (Foster, 2004) using the optimal model plus a polytomy prior (resolution class prior with $C=\log _{\mathrm{e}}(10)$; Lewis et al., 2005), and with a single composition vector (i.e., the composition was treehomogeneous). The composition homogeneity of each data set was tested using simulations of the posterior predictive distribution (PPD) (Bollback, 2002) of the $\chi^{2}$ statistic (Foster, 2004). If the data were shown to fail the PPD test of homogeneity, successive additional composition vectors were added using the node discrete composition heterogeneity model (NDCH; Foster, 2004; Cox et al., 2008) until the model composition fit the data (i.e., the $\chi^{2}$ statistic of the data could no longer be rejected as falling outside the simulated distribution at a $P<0.05$ level of significance). The multiple composition tree-heterogeneous NDCH models were considered optimal when the model composition fit could not be rejected. Each MCMC analysis was run for 2000000 generations with four parallel chains (i.e., Metropolis-coupled MCMC), and free parameter tuning values were automatically determined prior to the start of the MCMC. "Mixing" of the MCMC chains and effective sample size (ESS) scores of parameters were monitored so that the correct behavior of the MCMC could be assessed. Symmetrical mixing among adjacent chains and ESS values in excess of 300 were considered indications that the chain was behaving well. If the mixing was found to be inadequate the MCMC temperature parameter was adjusted and the chain restarted. If the ESS values were too low the chain was run for additional generations.

For all the MCMC described here, the "burnin" of each MCMC was determined by visual inspection of the log likelihood score across the sampled generations. Log marginal likelihoods of all MCMC analyses were calculated using eq. 5 of Newton and Raftery (1994) as implemented in p4.

A combined data set of the 60 taxa for the eight individual loci was constructed with previously identified ambiguous regions removed. All taxa had unique sequences across the combined eight genes. The optimal single model for the combined data set was determined by MrModeltest as described above. ML bootstrap analyses were conducted with 300 replicates using RAxML with a data-homogeneous $(\mathrm{GTR}+\Gamma)$ model. In addition, a data-heterogeneous ML bootstrap analysis (300 replicates) was conducted using a separate model $(\mathrm{GTR}+\Gamma \times 8)$ for each gene partition. Homogeneous MCMC analyses were conducted using MrBayes (vers. 3.1.2; Ronquist and Huelsenbeck, 2003) under a GTR $+\mathrm{I}+\Gamma$ model for 2000000 generations with the default two runs (each of four chains). Convergence between the two chains was assumed when the average standard deviation of split frequencies fell below 0.0001. Similar tree- and data-homogeneous MCMC analyses, but including a polytomy prior (GTR $+\mathrm{I}+\Gamma+\mathrm{P}$, other settings as above), were run in $\mathrm{p} 4$ for 2000000 generations as described previously. Model data-homogeneous but composition treeheterogeneous $(\mathrm{NDCH})$ analyses with two composition vectors and the polytomy prior $(\mathrm{GTR}+\mathrm{I}+\Gamma+\mathrm{NDCH}(2)+\mathrm{P})$ were conducted in $\mathrm{p} 4$ as described previously. A model data-heterogeneous and composition tree-heterogeneous MCMC analysis was conducted in $\mathrm{p} 4$ with a separate $\mathrm{NDCH}$ model for each partition (the optimal models found previously) with the polytomy prior and a partition-rate prior ([ssu:GTR $+\mathrm{I}+\Gamma+\mathrm{NDCH}(2)+1$ su:GTR $+\mathrm{I}+\Gamma+\mathrm{NDCH}(3)+$ rbcL:GTR $+\mathrm{I}+\Gamma+\mathrm{NDCH}(2)+\mathrm{rps} 4: \mathrm{GTR}+\Gamma+\mathrm{NDCH}(2)+\mathrm{psba}: \mathrm{GTR}+\mathrm{I}+\Gamma+$ $\mathrm{NDCH}(2)+\operatorname{trnG}: \mathrm{GTR}+\Gamma+\operatorname{trnL}: \mathrm{HKY}+\Gamma+\operatorname{nad} 7: \mathrm{GTR}+\Gamma+\mathrm{NDCH}(2)]+\mathrm{P}+\mathrm{R})$.

Bayesian MCMC analyses were also conducted with the software Phylobayes (vers. 2.3c; Lartillot and Philippe, 2004) under the CAT model with a mixture of multiple GTR substitution models and a gamma distribution of rates among sites $(\mathrm{CAT}-\mathrm{GTR}+\Gamma)$. Two separate runs were conducted for $\sim 1380000$ cycles, and results compared between chains using the "bpcomp" program to ensure that the chains had converged. After discarding the burnin of each chain, tree and parameter estimates were determined by combining the results of both chains. Posterior predictive simulations of the $\chi^{2}$ statistic were calculated using the Phylobayes software "ppred."

Phylogenetic analyses: Nine-taxon, 11-locus data set-A nine-taxon combined data set was constructed with the previous eight genes plus rpoCl, psbT, and nad5. ML bootstrap analyses were conducted using RAxML with 300 replicates under the optimal model. Tree-homogeneous MCMC analyses were conducted in $\mathrm{p} 4 \mathrm{using}$ the polytomy prior, and tree-homogeneous NDCH analyses were conducted with the addition of a second composition vector. Phylobayes analyses under the $\mathrm{CAT}+\mathrm{GTR}+\Gamma$ model were conducted for $\sim 130000$ cycles in a single run. Further details of the analyses are as described previously for the 60-taxon data set.

Genome size estimates-Sphagnum is relatively conservative in chromosome number; only gametophytic numbers of $N=19$ and $N=38$ have been documented (Fritsch, 1982) although indirect evidence (genetic data and flow cytometric analyses) have identified two southern hemisphere species that appear to have triploid gametophytes (Karlin et al., 2009). Genome size estimates for Ambuchanania 
leucobryoides, S. inretortum, and S. sericeum were undertaken to compare inferred ploidal levels in these species to gametophytically haploid and diploid taxa.

Flow cytometry (FCM) of herbarium samples was conducted using the Otto buffer system for isolating nuclei by chopping, propidium iodide as the DNA stain, and fresh Solanum pseudocapsicum $(1 \mathrm{C}=1.295 \mathrm{pg}$ or $1266.5 \mathrm{Mbp}$; Temsch et al., 2010) as a pseudo-internal standard. A Partec CyFlow flow cytometer equipped with a green laser was employed as described in Ricca et al. (2008).

Determination of nuclear Feulgen DNA content (FDM) from herbarium specimens with DNA image analysis used methods described previously for fixed fresh material and herbarium specimens of Sphagnum (Ricca et al., 2008). Apical meristems were detached from herbarium specimens under distilled water so that the smallest embryonic leaves and the meristem itself were immediately exposed to fixative chemicals. Fixation time in $4 \%$ phosphate-buffered formaldehyde ( $\mathrm{pH} \mathrm{7}$ ) was $90 \mathrm{~min}$ at $20^{\circ} \mathrm{C}$. In some instances (Ambuchanania [Buchanan 16981], S. inretortum [Price et al., 1236]), meristems were directly brought to $5 \mathrm{~N} \mathrm{HCl}$ without fixation. As a reference for staining intensity, embryonic meristems from dry seeds of Pisum sativum 'Kleine Rheinländerin' (2C $=8.84 \mathrm{pg}$; Greilhuber and Ebert, 1994) were processed synchronously and cut into pieces after about 5 min when softening had occurred. Formaldehyde was carefully removed with several rinses of methanol-acetic acid $(3: 1)$ for about $30 \mathrm{~min}$. This postfixative was removed with several rinses of distilled water. Hydrolysis in $5 \mathrm{~N} \mathrm{HCl}$ at $20^{\circ} \mathrm{C}$ was for $90 \mathrm{~min}$ (formaldehyde fixation) or for $60 \mathrm{~min}$ (no fixation), followed by a thorough wash in distilled water for 10 min. Staining in Schiff's reagent (Merck, Whitehouse Station, New Jersey, USA) was done for $90 \mathrm{~min}$ at $20^{\circ} \mathrm{C}$. Schiff's reagent was washed out for $30 \mathrm{~min}$ with $\mathrm{SO}_{2}$-water. The material was briefly softened in $45 \%$ acetic acid and squashed onto glass slides, standard and unknown side by side. Coverslips were removed over a cold-plate after freezing. The slides were air-dried and kept light-protected until measurement, which occurred within $48 \mathrm{~h}$.

Dye content of the Feulgen-stained nuclei was measured using the CIRES (Cell Imaging and Retrieveal System, Kontron, Munich), with a Zeiss $63 \times$ oil Plan Neofluar objective, using Köhler illumination and the green channel of the video camera, a green interference filter, a neutral density filter, the shading correction option, and local background determination (around each measured nucleus separately). Almost all geometrically suitable moss nuclei of a slide were measured (114 on average, from 7-314 per slide; i.e., those automatically segmentable and in clear background) and a similar number of standard $2 \mathrm{C}$ nuclei, but mostly not more than 100 , which is sufficient for a stable mean value.

DNA contents in Mbp (1C), were calculated using the ratio of moss nuclei ( $1 \mathrm{C}$ and $2 \mathrm{C}$ ) vs. standard $2 \mathrm{C}$ nuclei corrected to $1 \mathrm{C}$ according to the replication state, multiplied by $8.84 \mathrm{pg}$ or $8645.52 \mathrm{Mbp}$ (conversion factor pg to $\mathrm{Mbp}=$ 978; Doležel et al., 2003).

\section{RESULTS}

Phylogenetic reconstructions: 60-taxon, eight-locus data set-Total numbers of amplified nucleotides, numbers of nucleotides included in analyses after pruning regions of ambiguous alignment, and optimal substitution models for each locus are provided in Table 1. Single-locus reconstructions under maximum likelihood and Bayesian inference are shown in Appendix S1 (see the Supplemental Data at http://www.amjbot.org/cgi/ content/full/ajb.1000055/DC1, Figs. S.1.1-S.1.8 and S.1.9-S.1.16, respectively). The position of Polytrichadelphus purpureus with the outgroups in the rbcL NDCH analysis (Fig. S.1.11) appears to be anomalous and does not appear in the ML analysis of the data (Fig. S.1.3). No other significant incongruence was detected among single-locus reconstructions, and the eight loci were combined as a single concatenated matrix. A total of 4230 sites were excluded because of ambiguous alignment across the eight loci (Table 1). The combined matrix included 8498 nucleotide sites that were included in subsequent analyses. Of the 8498 included sites, 3380 represent the nuclear genome (nrDNA), 3378 the plastid genome, and 1740 the mitochondrial genome.

Phylogenetic reconstructions based on the combined eightlocus matrix were obtained using seven different combinations of analytical method (ML and Bayesian) and models of evolution (Table 2). The models ranged from a relatively simple homogeneous substitution pattern across taxa and sites, to one (model 6 in Table 2) with 123 parameters such that the analysis is both data heterogeneous for the substitution model and tree heterogeneous across each locus/partition. The Phylobayes CAT analysis (model 7 in Table 2) dynamically models composition heterogeneity across the data, but without having to prespecify which sites evolve under which composition (as in model 6).

Results of all analyses of the concatenated data are provided in online Appendix S1, supplemental Figs. S17-S25. Figure 1 shows the reconstruction from analyses under model 6 (Table 2), with bootstrap proportions and Bayesian posterior probabilities for critical nodes provided from that analysis and from three other models (see legend for Fig. 1). We focus here on relationships of Ambuchanania to other species traditionally classified in Sphagnum. Support for most other nodes on the tree are not shown; results from analyses of relationships within the class Bryopsida based on almost the same set of taxa and loci were described by Cox et al. (2004).

All analyses support the following inferences. The Sphagnopsida, including Ambuchanania and all species of Sphagnum, comprise a monophyletic group. Support is maximal under both ML and with all Bayesian models. A large group of Sphagnum species representing the traditional groups (subgenera or sections)

TABLE 1. Bayesian analyses of individual gene partitions for the 60-taxon, eight-gene data set.

\begin{tabular}{|c|c|c|c|c|c|c|c|}
\hline Locus & Taxa & Incl. $\operatorname{taxa}^{\mathrm{a}}$ & Total sites & Incl. sites ${ }^{b}$ & Optimal modelc & $P$-value ${ }^{\mathrm{d}}$ & $-\log _{\mathrm{e}}\left(L_{m}\right)^{\mathrm{e}}$ \\
\hline SSU & 56 & 43 & 1896 & 1619 & $\mathrm{GTR}+\mathrm{I}+\Gamma+\mathrm{NDCH}(2)+\mathrm{P}$ & 0.5784 & 4208.4413 \\
\hline LSU & 60 & 50 & 2275 & 1761 & $\mathrm{GTR}+\mathrm{I}+\Gamma+\mathrm{NDCH}(3)+\mathrm{P}$ & $0.0000^{f}$ & 5987.1519 \\
\hline$r b c L$ & 59 & 55 & 1659 & 1282 & $\mathrm{GTR}+\mathrm{I}+\Gamma+\mathrm{NDCH}(2)+\mathrm{P}$ & 0.9987 & 10187.1225 \\
\hline rps4 & 60 & 56 & 1063 & 568 & $\mathrm{GTR}+\Gamma+\mathrm{NDCH}(2)+\mathrm{P}$ & 0.6072 & 6094.2647 \\
\hline psba & 59 & 52 & 1712 & 1144 & $\mathrm{GTR}+\mathrm{I}+\Gamma+\mathrm{NDCH}(2)+\mathrm{P}$ & 0.7603 & 6766.5207 \\
\hline $\operatorname{trn} G$ & 58 & 44 & 1089 & 204 & $\mathrm{GTR}+\Gamma+\mathrm{P}$ & 0.0619 & 1811.1586 \\
\hline $\operatorname{trn} L$ & 57 & 44 & 1055 & 180 & $\mathrm{HKY}+\Gamma+\mathrm{P}$ & 0.4000 & 1183.5210 \\
\hline nad7 & 50 & 50 & 1979 & 1740 & $\mathrm{GTR}+\Gamma+\mathrm{NDCH}(2)+\mathrm{P}$ & 0.1881 & 5885.1619 \\
\hline
\end{tabular}

${ }^{a}$ Number of taxa included in analyses after identical sequences were reduced to a single representative.

${ }^{\mathrm{b}}$ Number of sites included after ambiguously aligned regions were excluded.

${ }^{\mathrm{c}}$ Optimal model for each locus: the substitution rate matrices and among-site rate variation parameters were determined by MrModeltest, and the optimal number of composition vectors determined by posterior predictive simulations of the $\chi_{m}^{2}$ statistic; $+\mathrm{P}$ indicates with the addition of the polytomy prior.

${ }^{\mathrm{d}} P$-value of the NDCH posterior predictive simulations of the $\chi^{2}{ }_{m}$ statistic.

${ }^{\mathrm{e}}$ Log marginal likelihoods calculated according to the Eq. 16 of Newton and Raftery (1994).

${ }^{\mathrm{f}}$ For the LSU data, three composition vectors did not fit: $\chi_{m}^{2}$ statistic of original data: 124.3 , range of statistic in posterior predictive simulations: 5.26 to 116.79 (in homogeneous data the range was 3.68 to 29.82 ). 
TABLE 2. Analyses of the concatenated 60-taxon, 8-locus data set, and posterior probability values for particular clades.

\begin{tabular}{|c|c|c|c|c|c|}
\hline Method & Model & $-\log _{\mathrm{e}}\left(L_{m}\right)$ & $P$-value a & A. + S.i. ${ }^{b}$ & A. + S.i. + S.s ${ }^{c}$ \\
\hline ML & 1. GTR $+\mathrm{I}+\Gamma$ & - & - & 0.38 & 0.28 \\
\hline ML & 2. $(\mathrm{GTR}+\mathrm{I}+\Gamma) * 8$ & - & - & 0.42 & 0.26 \\
\hline Bayesian & 3. GTR $+\mathrm{I}+\Gamma$ & 43571.4932 & 0.0000 & 0.96 & 0.49 \\
\hline Bayesian & 4. $\mathrm{GTR}+\Gamma+\mathrm{I}+\mathrm{P}^{d}$ & 43605.0018 & 0.0000 & 1.00 & 0.00 \\
\hline Bayesian & 5. $\mathrm{GTR}+\Gamma+\mathrm{I}+\mathrm{NDCH}(2)+\mathrm{P}$ & 43298.0001 & 0.9993 & 1.00 & 0.00 \\
\hline \multirow[t]{9}{*}{ Bayesian } & 6. data- and tree-heterogenous $+\mathrm{P}+\mathrm{R}^{e}$ & 42363.0379 & - & 1.00 & 0.02 \\
\hline & SSU: GTR+I+Г+NDCH(2) & - & 0.1596 & - & - \\
\hline & LSU: GTR $+\mathrm{I}+\Gamma+\mathrm{NDCH}(3)$ & - & 0.0000 & - & - \\
\hline & $r b c L: \mathrm{GTR}+\mathrm{I}+\Gamma+\mathrm{NDCH}(2)$ & - & 0.1160 & - & - \\
\hline & rps $4: \mathrm{GTR}+\Gamma+\mathrm{NDCH}(2)$ & - & 0.5318 & - & - \\
\hline & psba: $\mathrm{GTR}+\mathrm{I}+\Gamma+\mathrm{NDCH}(2)$ & - & 0.7384 & - & - \\
\hline & $\operatorname{trn} G: \mathrm{GTR}+\Gamma$ & - & 0.6814 & - & - \\
\hline & $\operatorname{trn} L: \mathrm{HKY}+\Gamma$ & - & 0.2182 & - & - \\
\hline & $\operatorname{nad} 7: \mathrm{GTR}+\Gamma+\mathrm{NDCH}(2)$ & - & 0.2182 & - & - \\
\hline Bayesian & 7. CAT-GTR $+\Gamma$ & 31205.3830 & 0.0602 & 0.99 & 0.56 \\
\hline
\end{tabular}

${ }^{a} P$-value of the $\mathrm{NDCH}$ posterior predictive simulations of the $\chi_{\mathrm{m}}^{2}$ statistic.

${ }^{\mathrm{b}}$ Bootstrap support or posterior probability for the clade Ambuchanania + Flatbergium inretortum.

${ }^{\mathrm{c}}$ Bootstrap support or posterior probability for the clade Ambuchanania + Flatbergium inretortum + Eosphagnum sericeum $858+$ E. sericeum 1239 .

${ }^{\mathrm{d}}$ Polytomy resolution class prior: $\mathrm{C}=\log 10$.

${ }^{\mathrm{e}} R$ : partition rate parameter.

Acutifolia, Cuspidata, Polyclada (S. wulfianum), Rigida, Sphagnum, Squarrosa, and Subsecunda, form a monophyletic group, also with maximal support from all analyses (Fig. 1, Sphagnum). Branch lengths appear extremely short within this clade, at least compared to branches throughout the rest of the tree. Nevertheless, monophyly of the traditional sections is significantly supported in most analyses (not shown in Fig. 1 but evident in Figs. S17-S25). The branches appear virtually nonexistent in Fig. 1 simply because they are very short relative to other branches in the reconstruction.

Two other species traditionally considered members of the genus Sphagnum fall outside Sphagnum s.s. (Fig. 1). Two samples of the Southeast Asian species, S. sericeum, are identical across all 8498 nucleotides included in these analyses but are together resolved as a separate clade of Sphagnopsida. Sphagnum inretortum of western South America is also resolved outside Sphagnum s.s. and is in fact strongly supported as sister to Ambuchanania leucobryoides by all Bayesian analyses, though not by ML bootstrapping (Fig. 1, Table 2). Relationships between $S$. sericeum, the clade containing Ambuchanania plus S. inretortum, and Sphagnum s.s. are not resolved; although all analyses converge on the inference that S. sericeum, S. inretortum, and Ambuchanania are outside the main clade of Sphagnum, no analysis supports $S$. sericeum, S. inretortum, and Ambuchanania in a single clade sister to Sphagnum s.s. (Table 2). Branch lengths indicate that these three taxa outside the main Sphagnum clade are each highly distinct at the molecular level compared to any species within Sphagnum s.s., even those in different traditional sections.

Phylogenetic reconstructions: nine-taxon 11-locus data set-Primarily because of the unexpected result from analyses of the 60-taxon, eight-locus data set that Ambuchanania leucobryoides and Sphagnum inretortum were resolved as sister species, we developed a second data set with fewer taxa and more nucleotide characters. During the course of this study, a second (Chilean) sample of $S$. inretortum became available so we included it in these analyses. The final analyzed data set included 11705 nucleotide sites (Table 3), with 739 informative characters under parsimony. Base compositions of the individual loci and the concatenated data set are provided in Table 4 .
Reconstructions from analyses of the concatenated 11-locus data set were rooted with Andreaea and Takakia. All analyses support a monophyletic Sphagnopsida with maximal support. Moreover, all analyses resolve three clades of Sphagnopsida, one including the two samples of $S$. sericeum, another including the two exemplars of Sphagnum s.s. (represented by S. palustre [section Sphagnum] and S. lescurii [section Subsecunda]), and the third including Ambuchanania plus the two samples of S. inretortum. The clade including Ambuchanania plus S. inretortum is supported by Bayesian posterior probabilities of 1.0 in analyses employing a homogeneous substitution model, and in two analyses employing heterogeneous models of varying complexity (see legend for Fig. 2). Under maximum likelihood, this clade is moderately supported by bootstrapping $(0.71$; Fig. 2$)$. The two samples of S. inretortum are identical across all 11705 nucleotides, as are the two samples of S. sericeum. It is worthy of note that although monophyly of Ambuchanania plus S. inretortum is strongly supported by these analyses, branch lengths show that they are phylogenetically divergent compared to, for example, S. palustre and S. lescurii, representing two sections within the traditional genus Sphagnum.

In an additional test of the inference that Ambuchanania and S. inretortum are sister taxa, rather than Ambuchanania being sister to all remaining Sphagnopsida, we constrained the tree in a Bayesian MCMC $(\mathrm{GTR}+\mathrm{I}+\Gamma+\mathrm{NDCH}(2)+\mathrm{P})$ to force the monophyly of Sphagnum, including S. sericeum and S. inretortum. This constraint forces a topology in which A. leucobryoides is the sister group to the rest of the Sphagnopsida. The constraint analysis tree had a marginal likelihood of -25727.9892 (Table 3, model 5; online Fig. S.1.28), compared to the same analysis without the constraint: -25708.5622 (Table 3, model 3; online Fig. S.1.24). The difference of 19.427 likelihood units favors the unconstrained analyses that places Ambuchanania as sister to $S$. inretortum. A Bayes Factor $\left(2 \log _{\mathrm{e}}(\mathrm{M} 1 \mid \mathrm{M} 2)=2 \times\right.$ 19.427) of 38.854 strongly favors this interpretation.

Genome size estimates and inferences about ploidy-With Feulgen image densitometry, positively stained nuclei were obtained from one (Buchanan 16981) of two Ambuchanania vouchers and from all five Sphagnum vouchers (Table 5). One 


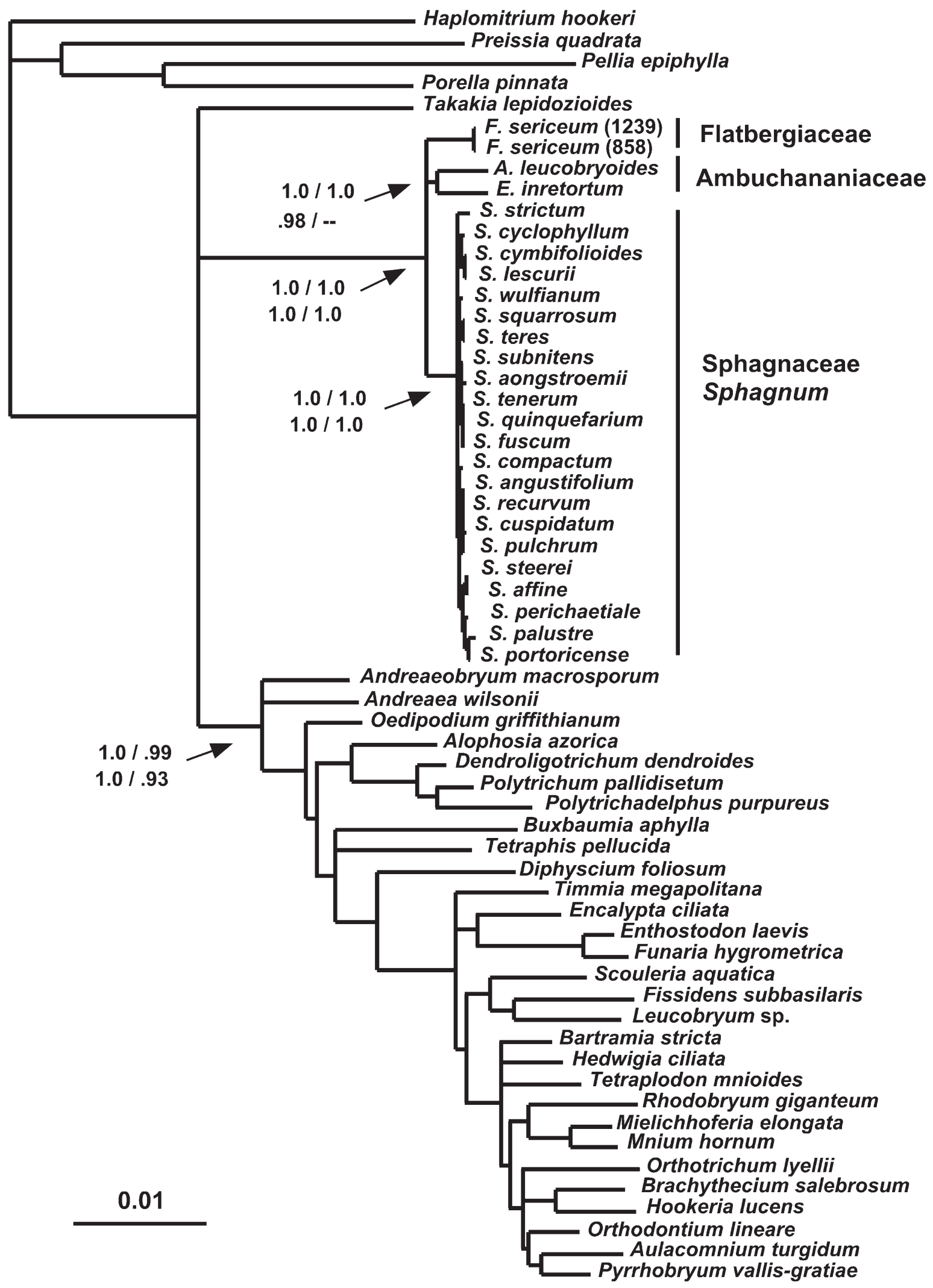

Fig. 1. Phylogram showing inferred relationships among mosses (Phylum Bryophyta) based on Bayesian analyses of the 60-taxon, eight-locus data set under the heterogeneous across-data across-tree substitution model (no. 6 in Table 2). Four support values associated with nodes are as follows (models listed in Table 2): upper left, model 5; upper right, model 6; lower left model 7; lower right, model 2. 
TABLE 3. Analyses of the concatenated 9-taxon, 11-locus data set.

\begin{tabular}{|c|c|c|c|}
\hline Method & Model & $-\log _{\mathrm{e}}\left(L_{m}\right)$ & $P$ a \\
\hline ML & 1. GTR $+\mathrm{I}+\Gamma$ & - & - \\
\hline Bayesian & 2. $\mathrm{GTR}+\Gamma+\mathrm{I}+\mathrm{P}^{\mathrm{b}}$ & 25813.5131 & 0.0000 \\
\hline Bayesian & 3. $\mathrm{GTR}+\mathrm{I}+\Gamma+\mathrm{NDCH}(2)+\mathrm{P}$ & 25708.5622 & 0.3080 \\
\hline Bayesian & 4. CAT-GTR $+\Gamma$ & 21932.8669 & 0.0000 \\
\hline Bayesian & 5. $\mathrm{GTR}+\mathrm{I}+\Gamma+\mathrm{NDCH}(2)+\mathrm{P}+$ constraint $^{\mathrm{c}}$ & 25727.9892 & 0.4007 \\
\hline
\end{tabular}

\footnotetext{
a $P$-value of the NDCH posterior predictive simulations of the $\chi_{m}^{2}$ statistic.

b Polytomy resolution class prior: $\mathrm{C}=\log 10$.

${ }^{\mathrm{c}}$ A topological constraint was introduced so that Ambuchanania was the sister group to all "sphagnum" species.
}

recent Ambuchanania sample from 2008 had no embryonic leaves and exhibited no nuclei at all, perhaps because there was cytoplasmic decay before drying occurred. Flow cytometry was unsuccessful as well. Previous experience has shown that Sphagnum herbarium specimens (1) give progressively lower Feulgen readings with increasing age, and (2) require optimal drying for good results. It was thus expected that specimens as old as 29 yr would result in data that could only be regarded as minimum values for genome size, which in vivo would almost certainly be higher. Nevertheless, the size of the nuclei could be used as additional criterion for inferring ploidy. For comparison, a voucher of S. girgensohnii from 1990 was Feulgenstained. Two slides from two capitula of this sample had 1C-values of 271.3 and $312.2 \mathrm{Mbp}$, indicating high interslide variation (here 1.15 -fold) and 0.58 to 0.71 -fold reduced staining compared to fresh material, for which $1 \mathrm{C}=442-467 \mathrm{Mbp}$ has been reported (Temsch et al., 1998; Bennett and Leitch, 2005).

Comparison of FDM with an FCM estimate was possible for the Chilean sample of $S$. inretortum, which was only 6 mo old and therefore recent enough that reliable genome size data could be obtained using both methods. This species had 353.7 Mbp (a relatively low haploid value) with FCM and maximally 292.8 Mbp with Feulgen densitometry, 0.83-fold lower than the FCM-derived value. This indicates some decay of DNA during preservation over the 6-mo period because fresh vouchers typically give similar values with FDM and FCM (Ricca et al., 2008). Five slides (branch tips) were measured with FDM and varied 1.14-fold between 256.3 and $292.8 \mathrm{Mbp}$. For S. inretortum, nine slides (branch tips) yielded values between 212.4 and 289.8 Mbp (1.36-fold variation). The lowest FDM values

TABLE 4. Bayesian analyses of individual gene partitions for the ninetaxon, 11-locus data set, listing the number of taxa included in each analysis, total nucleotide sites in each partition, numbers of included (Incl.) sites (after exclusion of sites because of ambiguous alignment), and numbers of parsimony informative (Pars. inf.) sites.

\begin{tabular}{lcccc}
\hline \hline Locus & Taxa & Total sites & Incl. sites & Pars. inf. \\
\hline SSU & 9 & 1823 & 1775 & 64 \\
LSU & 8 & 2141 & 1957 & 40 \\
rbcL & 9 & 1455 & 1099 & 87 \\
rps4 & 9 & 932 & 586 & 73 \\
rpoC1 & 7 & 803 & 803 & 82 \\
psbA & 9 & 1719 & 1267 & 71 \\
psbT & 8 & 540 & 453 & 36 \\
trnG & 8 & 850 & 487 & 51 \\
trnL & 9 & 918 & 293 & 29 \\
nad5 & 9 & 1938 & 1120 & 119 \\
nad7 & 9 & 1935 & 1865 & 87 \\
\hline
\end{tabular}

(Table 5) were, not surprisingly, recorded for S. sericeum collected in 1982 and 1980 (i.e., vouchers 26 and 28 yr old).

For Ambuchanania, a sample approximately 1 yr old yielded an estimate of $256 \mathrm{Mbp}$ from one meristem, with a CV of $5.3 \%$ in $1 \mathrm{C}$ nuclei, which is normal. The nuclei appeared shrunken and irregular in form, but well stained. Their size was relatively small, and the nuclear DNA content implies a ploidal level of not more than haploidy, provided the genome is comparable in structure to a Sphagnum genome.

The high and certainly artifactual variation between slides of one sample made it futile to use mean values of accessions as a best-estimate of genome size. Rather, the slides with highest Feulgen values and therefore least DNA loss were considered the best estimates for inferring ploidal level (Table 5). In summary, genome sizes for all five Sphagnum samples and Ambuchanania are small enough to exclude the possibility that they correspond to polyploid species of Sphagnum (i.e., diploid gametophytes, $N=38$ ). One cannot, however, exclude the possibility that the particularly low values in $S$. sericeum indicate an even smaller genome size and chromosome number than is typical for haploid sphagna, which have 1C-values between 383 and $495 \mathrm{Mbp}$, while diploid species have between 796 and $931 \mathrm{Mbp}$ (Temsch et al., 1998). This ranks relatively low but well within the bryophyta, with mosses (Voglmayr, 2000) having 1C-values between 170 and $2112 \mathrm{Mbp}$, and liverworts between 206 and $7791 \mathrm{Mbp}$ (Temsch et al., 2010).

Morphological observations-We describe here the salient morphological characteristics of the three taxa resolved by phylogenetic analyses as outside the core clade of Sphagnum species, but within the deeper Sphagnopsida clade. Our focus is on those features that agree, or not, with typical morphological traits of species traditionally included in the genus Sphagnum. More exhaustive descriptions of morphology for S. sericeum was provided by Eddy (1977), for S. inretortum by Crum (1990, 2001a), and for Ambuchanania leucobryoides by Yamaguchi et al. (1990).

Sphagnum sericeum-In terms of whole-plant architecture, $S$. sericeum is a "mainstream" Sphagnum. Sporophytes are borne on pseudopodia as in other Sphagnum species; there are abundant pseudostomata among the capsule exothecial cells (Fig. 3A). Aside from an unusually glossy appearance of the gametophytes (when dry), the plants do not stand out as aberrant relative to other species of Sphagnum. They are relatively robust, to $10 \mathrm{~cm}$ or more in length, with well-developed terminal capitula and lateral branches in fascicles of 3-4 (Fig. 3A). Within each fascicle, there are typically two spreading branches and 1-2 pendent branches. In cross-section, the stems have a small central zone of thin-walled cells surrounded by a well-defined region of small thick-walled cells (the so-called wood-cylinder), as in most species of Sphagnum. On the outside, there is an abruptly differentiated cortex with (2-)3 layers of enlarged thin-walled cells (Fig. 3B). The cortex of branches consists of rectangular nonporose cells and well-differentiated retort cells (Fig. 3C).

The stem leaves of $S$. sericeum are ovate-triangular with abruptly acute to cuspidate apices (Fig. 3I). The branch leaves are more gradually acute to acuminate, widest at about midleaf (Fig. 3J). Perichaetial leaves are larger than vegetative stem or branch leaves, with gradually acuminate apices (Fig. 3D).

It is the structure of the leaf cells that sets $S$. sericeum apart from most other species of Sphagnum. Most significantly, 


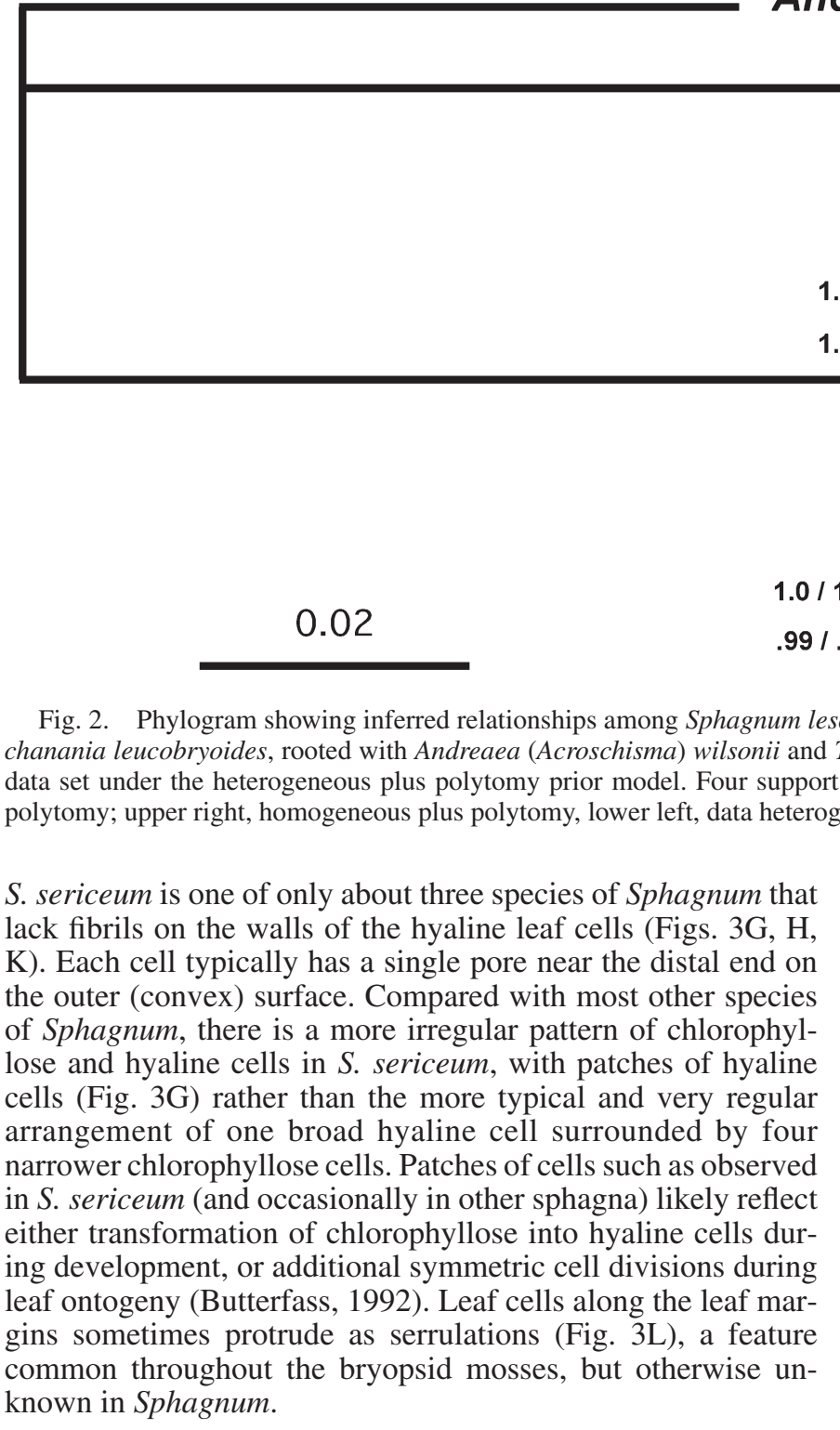

Sphagnum inretortum - This is a robust plant, pale whitishgreen and somewhat reminiscent of species in Sphagnum section Sphagnum (Fig. 4A, B). When Crum (1990) described
Takakia lepidozioides

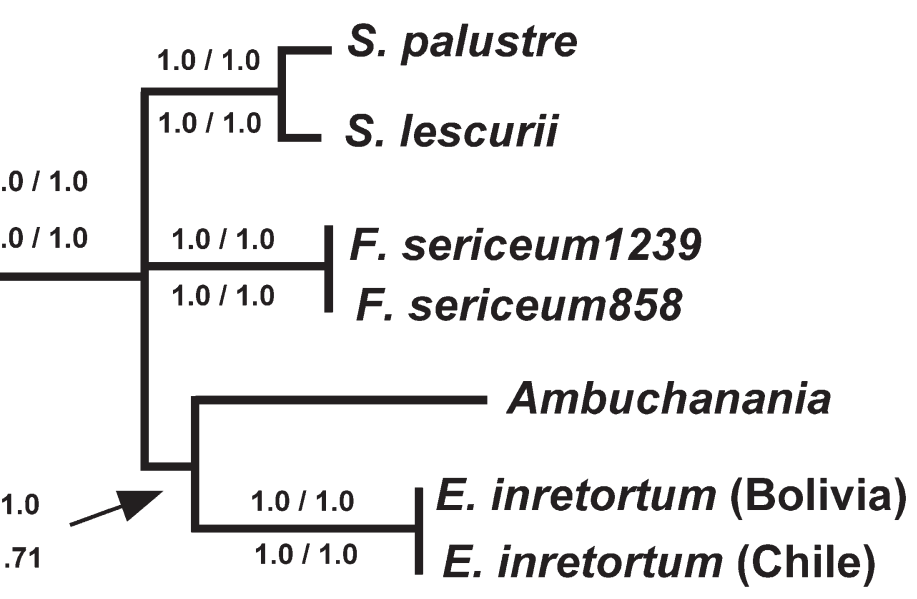

TABLE 5. Nuclear Feulgen DNA contents for herbarium specimens of Ambuchanania and Sphagnum species. Values for 1C nuclei from slides with worst (lowest) and best (highest) staining are shown. If not indicated otherwise, samples were processed using formaldehyde fixation

\begin{tabular}{|c|c|c|c|c|c|}
\hline \multirow[b]{2}{*}{ Species } & \multirow[b]{2}{*}{ Collector, voucher } & \multirow[b]{2}{*}{ Year (age, yr) } & \multicolumn{3}{|c|}{ Feulgen DNA content, $1 \mathrm{C} \mathrm{Mbp}(N ; \mathrm{CV} \%)$} \\
\hline & & & No. of slides & Lowest slide & Highest slide \\
\hline Ambuchanania & Buchanan, 16981 & $?$ & 1 & - & $256.0(150 ; 5.78)^{\mathrm{a}}$ \\
\hline S. sericeum & Damman \& Larsen, A81386 & $1982(17)$ & 2 & $128.5(30 ; 6.45)$ & $185.6(100 ; 4.65)$ \\
\hline S. sericeum & Lai, 11370 & $1980(29)$ & 1 & - & $127.7(223 ; 10)$ \\
\hline S. sericeum & Yamaguchi et al., 18926 & $2000(9)$ & 1 & - & $223.1(54 ; 9.62)$ \\
\hline S. inretortum & Price et al., 1236 & $1999(10)$ & 9 & $212.4(100 ; 3.92)$ & $289.8(34 ; 5.88)^{\mathrm{a}}$ \\
\hline S. inretortum ${ }^{\mathrm{b}}$ & Andrus, 11835 & $2008(<1)$ & 5 & $256.3(49 ; 8.62)$ & $292.8(100 ; 4.48)^{\mathrm{b}}$ \\
\hline S. girgensohnii & R. Krisai ${ }^{c}$ & 1990 (19) & 2 & $271.3(251 ; 7.35)$ & $312.2(251 ; 5.13)$ \\
\hline
\end{tabular}

${ }^{a} \mathrm{HCl}$ hydrolysis occurred without previous fixation.

b $1 \mathrm{C}=353.7 \mathrm{Mbp}$ estimated using flow cytometry.

c Lungau, Salzburg, Lessachtal, “Bacherlalm,” 1 July 1990.

S. inretortum from Bolivia he proposed a new section of Sphagnum to accommodate it (sect. Inretorta $\mathrm{H}$. A. Crum). The main feature, as the name suggests, was the absence of retort cells in the branch cortex. Crum noted that the branch leaves of $S$. inretortum have a marginal resorption furrow (as in sections Sphagnum, Rigida, and a few species of Acutifolia) but lacks the cucullate branch leaf apices and fibrillose stem and branch cortical cells of section Sphagnum. He compared S. inretortum to species in sections Rigida and Subsecunda (the latter because of similarities in stem cross sectional anatomy) but eliminated these sections from consideration because of various incompatibilities. About 10 years later, Crum (2001a) described S. lapazense, also based on plants collected in Bolivia. The type collection of S. lapazense was collected in Departmento La Paz, as was $S$. inretortum, and the plants are very similar. Crum (2001a), however, assigned S. lapazense to the section Sphagnum. An additional collection that is very similar morphologically to the types of S. inretortum and S. lapazense was recently collected in Chile (J. Larraín and R. Andrus, unpublished data). Although there are some seemingly significant anatomical 

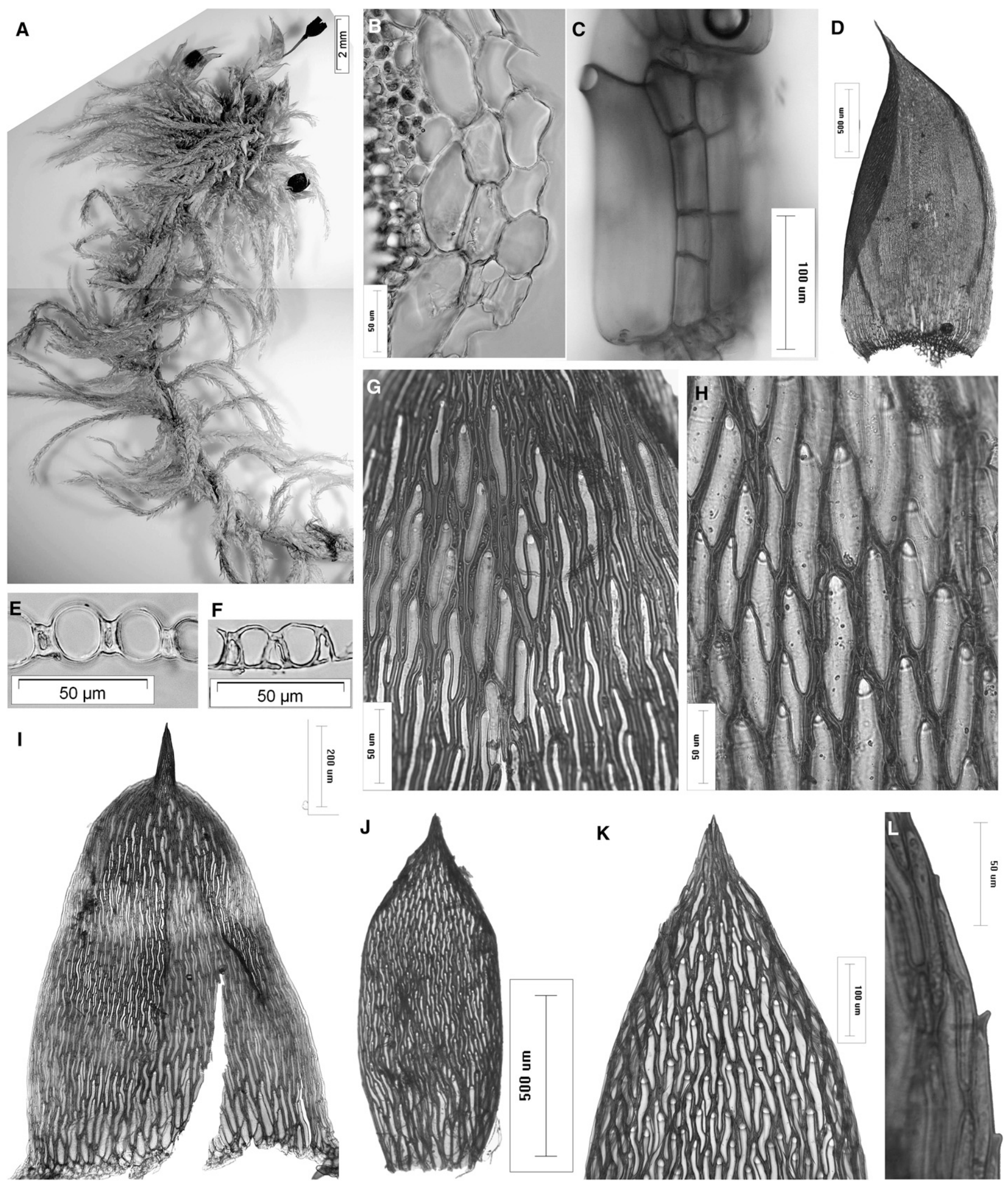

Fig. 3. Morphological characters of Flatbergium sericeum. (A) Gametophyte plant bearing sporophytes (Carr 15198). (B) Stem, transverse section (Yamaguchi 18295). (C) Branch cortex, showing retort cells and smaller nonporose cells (Carr 15198). (D) Perichaetial leaf (Yamaguchi 18295). (E, F) Branch leaf, transverse sections (Carr 15198). (G) Upper stem leaf cells, inside surface (Yamaguchi 18295). (H) Upper stem leaf cells, outside surface (Carr 15198). (I) Stem leaf (Yamaguchi 18295). (J) Branch leaf (Yamaguchi 18295). (K) Upper branch leaf, outside surface (Yamaguchi 18295). (L) Upper branch leaf, marginal cells (Carr 15198). All voucher specimens in DUKE. 
differences between these three specimens (discussed below), we currently interpret them as conspecific and refer to them as $S$. inretortum. We were not able to obtain sequence data from the type of $S$. inretortum, but the type of $S$. lapazense and the recent Chilean collection are identical across 11705 nucleotide characters. The species-level systematics of $S$. inretortum is worthy of additional study when additional collections come to light.

In cross section, the stems in all three collections have a central zone of thin-walled cells internal to a gradually differentiated wood cylinder of thicker-walled cells and a single layer of thin-walled cortical cells (Fig. 4E). Species of section Sphagnum are characterized by a multistratose cortex, typically with three layers of enlarged thin-walled cells. Stem leaves of the Chilean specimen are ovate and broadly acute, broadest about midway up the leaf (Fig. 4G). Stem leaves of the S. inretortum and $S$. lapazense type specimens have straighter margins and somewhat more abruptly narrowed apices, but it was difficult to isolate well-formed stem leaves from either specimen. A stem leaf from the $S$. inretortum specimen (Fig. $4 \mathrm{H}$ ) is lingulate-oblong and broadly acute and that of the $S$. lapazense specimen is similar (not shown).

Branches in all three specimens (the types of $S$. inretortum and $S$. lapazense, and the Chilean collection) lack cortical retort cells. Rather, all cortical cells are elongate-rectangular and aporose (Fig. 4C). Branch leaves in the three specimens are similar in shape, but those of the Chilean specimen are substantially larger (Fig. 4I-K). The branch leaves have weakly inrolled apices, not as cucullate as is characteristic of species in section Sphagnum, though more so than is typical of plants in other sections. They lack the resorption of outer hyaline cell walls near the leaf apices; such resorption is highly characteristic of species in section Sphagnum.

Branch leaves have stout, sometimes branched fibrils (Fig. 5E-I). On the outer surface, the hyaline cells have irregular longitudinal pleats that seem to derive from some kind of cuticular layer (Fig. 5G-I, best seen in the type of S. lapazense; Fig. 5G). This feature appears to be associated with the fact that plants are exceptionally difficult to wet because they very slowly take up even hot water.

Stem leaf cells of the Chilean plants (Fig. 5C) have abundant, round outer pores and few inner pores, whereas the S. lapazense (Fig. 5D) and S. inretortum (not shown) types have few outer pores but abundant, round inner pores. Paralleling differences in pore patterns on the inner and outer hyaline cell surfaces of stem leaves among the three collections, branch leaves also differ in pore patterns on the inside and outside surfaces of the hyaline cells. The Chilean plants (Fig. 5I) and the type of S. inretortum (Fig. $5 \mathrm{H}$ ) have abundant round pores on the outer surfaces of the hyaline cells but few scattered pores on the inner surfaces $(S$. inretortum shown in Fig. 5F). In contrast, the type of $S$. lapazense has few or no pores on the outer surfaces (Fig. 5G) and abundant, round pores on the inner surfaces (Fig. 5E).

All three specimens have branch leaf chlorophyllose cells that are lenticular and included, or nearly so, in transverse view (Fig. 4M, N). They all also have a marginal resorption furrow that can be seen either in transverse view (Fig. 4L) or as a ragged leaf margin in surface view (Fig. 5D).

Some of the Chilean plants had sporophytes borne on pseudopodia (Fig. 4A), as did some plants in the type of S. inretortum (Fig. 4D). The sporophyte exothecial cells are short-rectangular as is typical for Sphagnum, and pseudostomata are abundant (not shown). The pseudopodia in the Chilean plants are barely exerted from the bushy capitulum, whereas those in the S. inre- tortum type are conspicuously elongate (Fig. 4D). Well-developed perichaetial leaves are carried upward on the pseudopodia of the $S$. inretortum type, and these are gradually differentiated in size and shape from the vegetative leaves (Fig. 4F). Upper cells of perichaetial leaves tend to be devoid of pores, and the fibrils consist of stout but incomplete thickenings (Fig. 5A, B).

Despite the presence of sporophytes in two of the three collections, we did not observe antheridia, either on the same plants with sporophytes or on separate plants.

Ambuchanania-Unlike the previous two species, Ambuchanania is highly divergent in gross morphology and anatomical detail from any species of Sphagnum. The plants are relatively small, generally about $0.5-3 \mathrm{~cm}$ in length (and maybe longer but mostly buried in sand when growing) and without terminal capitula or branch fascicles (Fig. 6A, B). In nature, the plants are mostly buried in their sandy substrates, except for apical portions of the gametophytes. The leaves are exceptionally large, especially considering the diminutive size of the whole plants, and are erect and loosely imbricate wet or dry. Although fasciculate branching is absent, the plants can have lateral branches, which appear to be of two more or less distinct types, either slender with very small leaves (Fig. 6B, left arrow) or more stout with much larger leaves (Fig. 6B, right arrow). The slender branches with small leaves eventually do produce larger leaves (observed but not illustrated). Stems consist of more or less uniform cells in transverse section (Fig. 6C); a clear wood cylinder of thick-walled cells is absent, as are abruptly differentiated cortical cells. Branch axes have uniform cortical cells, and retort cells are absent (Fig. 6D). In transverse view, the branches are like slender stems.

Leaves have dimorphic hyaline and chlorophyllose cells (Fig. $6 \mathrm{E})$. Viewed from the inner or outer convex surface, the hyaline cells are rounded hexagonal to rhombic (Fig. 6K). In transverse section, large hyaline cells that reach the inner concave and outer convex surfaces alternate in a fairly regular fashion with smaller triangular hyaline cells that are transversely adjacent to small lenticular to tear-drop shaped chlorophyllose cells (Fig. 6I). Developmental studies of how the dimorphic hyaline and chlorophyllose cells differentiate are needed, but the transverse adjacency of the smaller triangular hyaline cells and the chlorophyllose cells suggests that each pair may be derived from a cell division during leaf ontogeny. Their transverse adjacency results in the leaf being bistratose between the larger hyaline cells that extend from the inner to outer leaf surface. This pattern is fairly regular, but irregularities in cell division patterns are also apparent. The arrangement of hyaline and chlorophyllose cells making up leaves of Ambuchanania suggest a very different developmental sequence relative to the well-documented ontogeny in Sphagnum leaves; cell structure in the leaves of S. sericeum and $S$. inretortum, in contrast, do not suggest any significant deviation from the "normal" Sphagnum mode of development.

Along the leaf margins, hyaline cells become narrow and elongate, forming a strongly but gradually differentiated border (Fig. 6I, arrow). Cell wall fibrils and pores are essentially lacking on leaves of main stems; very sparse and tiny pores occur occasionally near the leaf bases (Fig. 6J, arrows). The long, tubular leaves of the short branches (Fig. 6B, right arrow), however, have highly differentiated leaf cells, especially distally, with strong wall fibrils (Fig. 6H) and remarkably large, strongly ringed pores on the inner surfaces (Fig. 6F, G). No other member of the Sphagnopsida has such large or uniquely ringed pores. In the upper leaf parts these pores occur one per cell (Fig. 6G). 

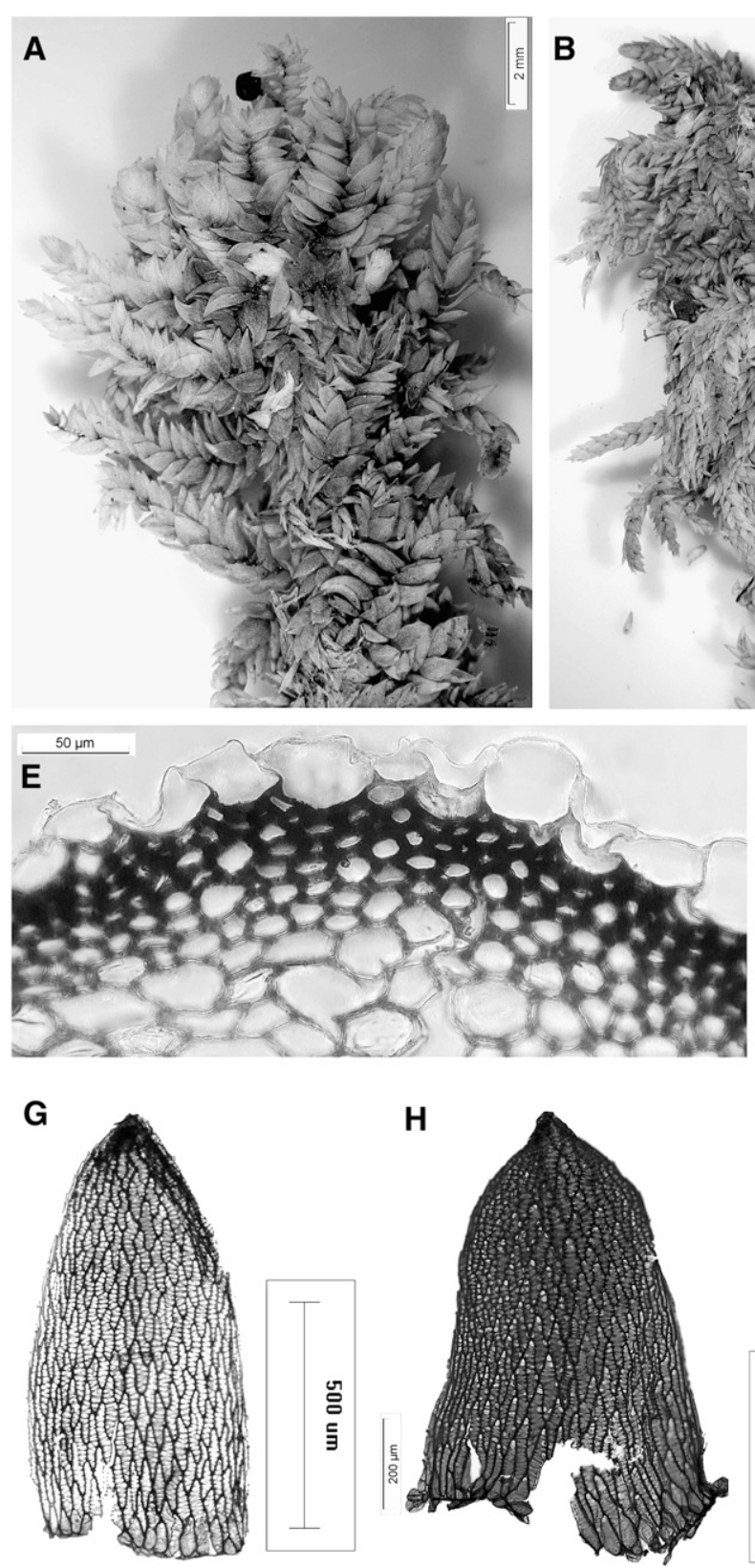

$\mathbf{L}$
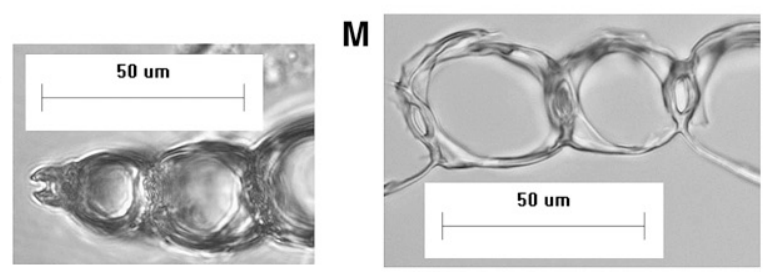
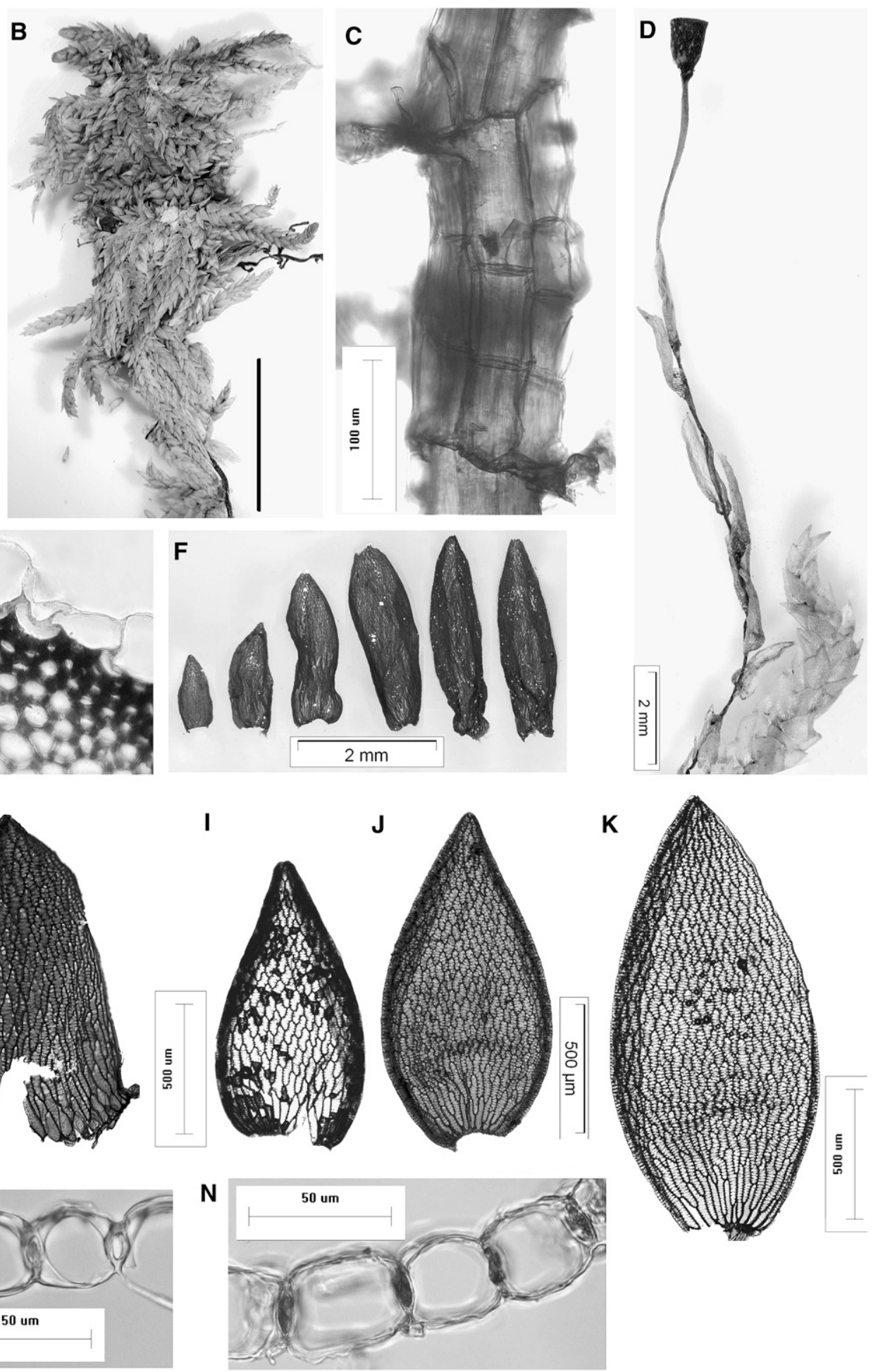

Fig. 4. Morphological characters of Eosphagnum inretortum. (A) Gametophyte plant bearing sporophytes (Larraín 31203). (B) Gametophyte plant (Feuerer, 1981). (C) Branch cortex showing absence of retort cells (Feuerer, 1981). (D) Pseudopodium with perichaetial leaves and terminal sporophyte (Feuerer, 1981). (E) Stem, transverse section (Feuerer, 1981). (F) Leaf transition from upper gametophyte to differentiated perichaetial leaves on pseudopodia (Feuerer, 1981). (G) Stem leaf (Andrus 11835). (H) Stem leaf (Feuerer, 1981). (I) Branch leaf (Price 1236). (J) Branch leaf (Feuerer, 1981). (K) Branch leaf (Andrus 11835). (L) Branch leaf marginal resorption furrow (Andrus 11835). (M) Branch leaf, transverse section (Andrus 11835). (N) Branch leaf, transverse section (Price 1236). All voucher specimens in DUKE. 
A

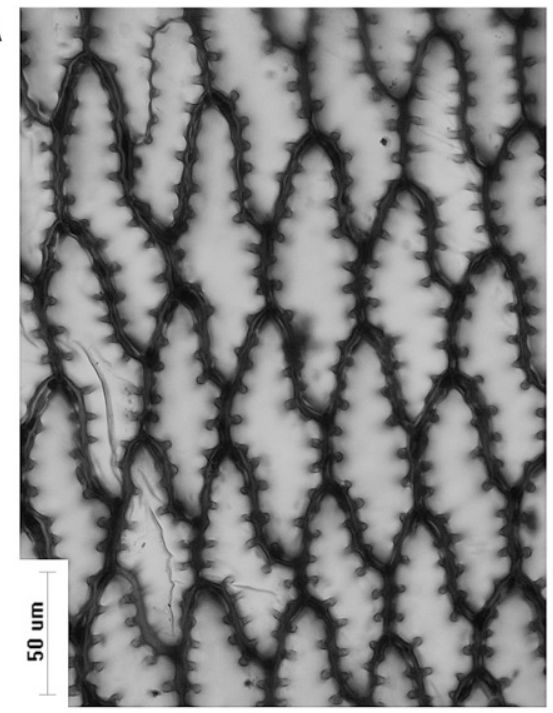

D

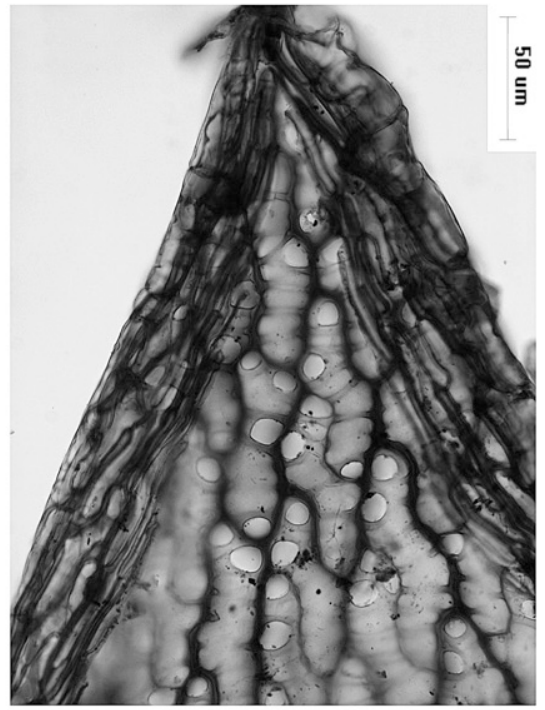

G

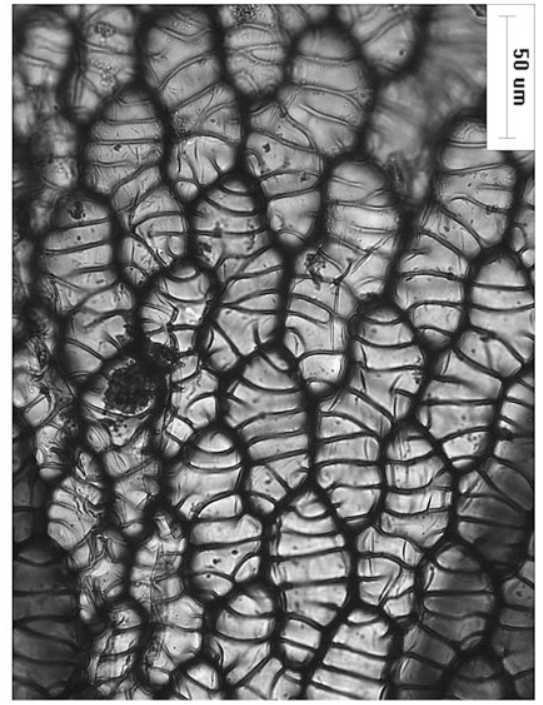

B

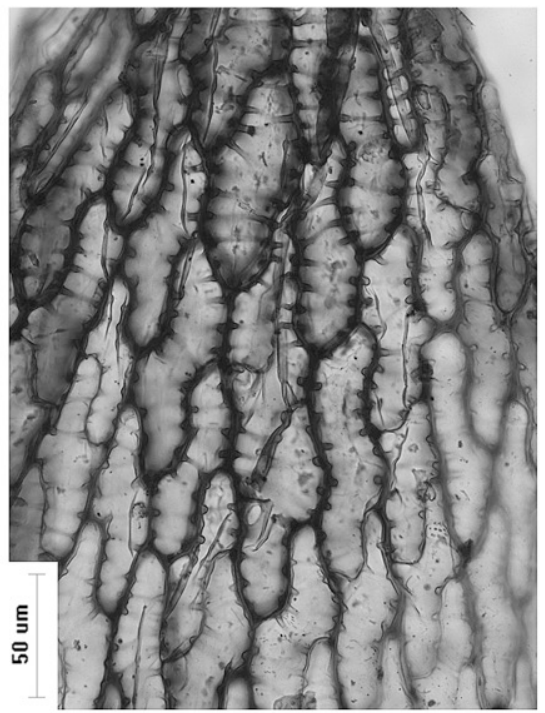

E

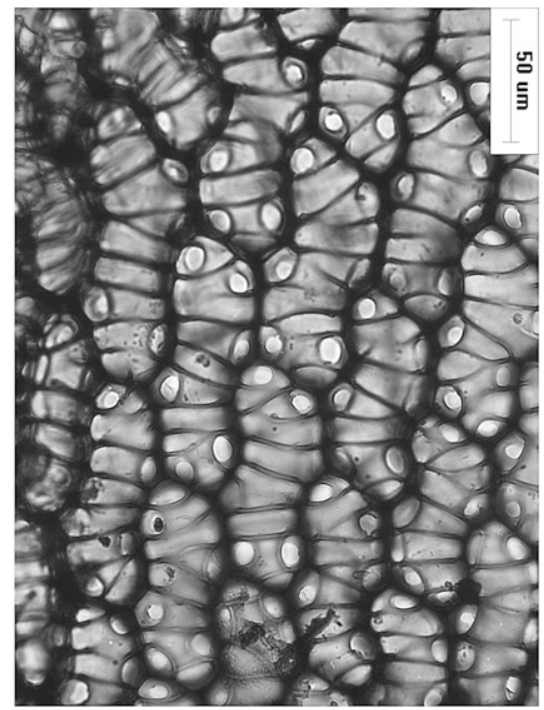

H

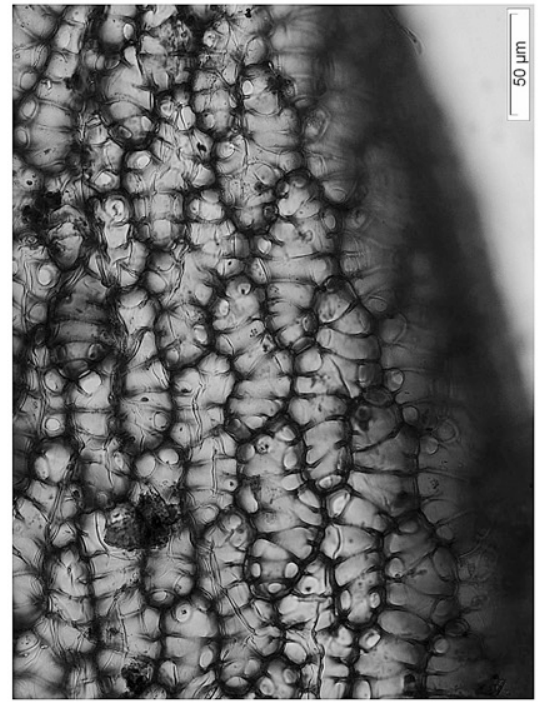

C

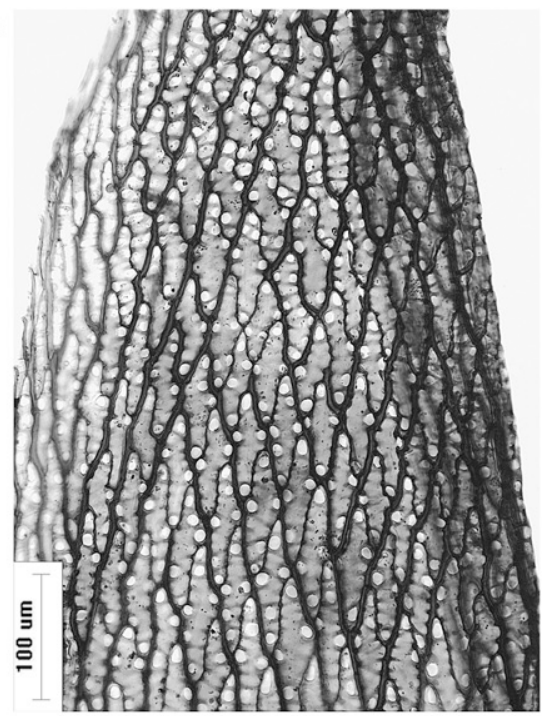

$\mathbf{F}$

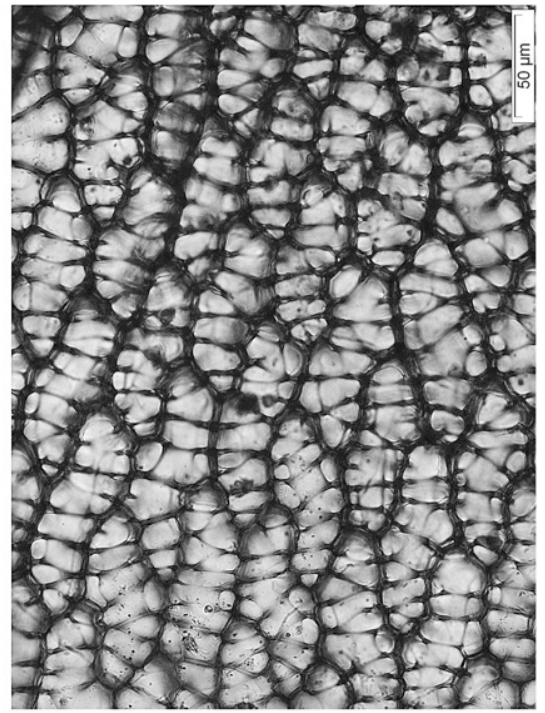

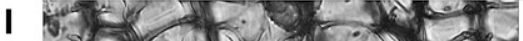

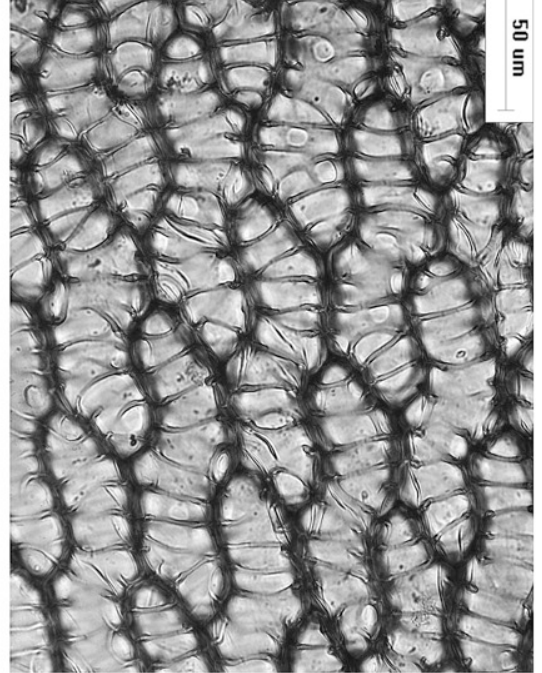

Fig. 5. Upper leaf cells of Eosphagnum inretortum. (A) Upper perichaetial leaf, outer surface (Larrain 31203). (B) Stem leaf, outer surface (Price 1236). (C) Stem leaf, outer surface (Andrus 11835). (D) Stem leaf, inner surface (Price 1236). (E) Branch leaf, inner surface (Price 1236). (F) Branch leaf, inner surface (Feuerer, 1981). (G) Branch leaf, outer surface (Price 1236). (H) Branch leaf, outer surface (Feuerer, 1981). (I) Branch leaf, outer surface (Andrus 11835). All voucher specimens in DUKE. 


\section{DISCUSSION}

Proposed classification for the Sphagnopsida-Faced with the problem of how to classify diversity within the Sphagnopsida in a way that best reflects phylogenetic relationships, the following observations are relevant. (1) There is a core clade of phylogenetically and morphologically cohesive group of species. (2) Species within that core clade are extremely closely related genetically/phylogenetically. (3) Sphagnum sericeum is unique morphologically relative to any species or groups of species within the core clade of Sphagnum. (4) Ambuchanania leucobryoides plus Sphagnum inretortum form a strongly supported clade that is also outside the core clade of Sphagnum species. (5) Ambuchanania leucobryoides and S. inretortum are highly divergent morphologically, and there are no apparent synapomorphies for the clade containing these two species.

We propose a new classification for the Sphagnopsida that takes each of these observations into account. Sphagnum sericeum is sufficiently distinct morphologically and, especially in terms of molecular divergence, to warrant recognition in a separate genus and family. Phylogenetic divergence relative to core Sphagnum species and the sister-group relationship between Ambuchanania and $S$. inretortum warrants the placement of these two taxa in a separate family, Ambuchananiaceae, in two separate genera. The remaining species, all closely related and traditionally classified in the genus Sphagnum are retained in that genus, classified as the Sphagnaceae. Segregation of S. sericeum and S. inretortum in families separate from Sphagnum (Sphagnaceae) will displease some, because both species have the capitulate gametophytes with fasciculate branching characteristic of that genus. However, this taxonomic solution best reflects phylogenetic relationships and evolutionary divergence. In terms of the practical consequences of this proposed taxonomic treatment of the Sphagnopsida, it is worth noting that all of the northern hemisphere work on peatland ecology will still deal exclusively with peatmosses classified in Sphagnum; the new classification will have little impact on this ecological field.

A primary division of Sphagnum into groups that correspond to subgenus or section Sphagnum vs. all other groups (Andrews, 1911) is not supported by molecular phylogenetic analyses (Shaw et al., 2003). Sphagnum is divided here into six subgenera corresponding to traditionally recognized groups (e.g., Lindberg, 1882; Warnstorf, 1911; Isoviita, 1966; Crum, 1984). The subgenus Acutifolia is divided into three sections to reflect close phylogenetic relationships between $S$. wulfianum (sect. Polyclada), S. aongstroemii (sect. Insulosa) and the core Acutifolia (sect. Acutifolia). Shaw et al. (2005) resolved a well-supported monophyletic group that includes the core Acutifolia plus S. wulfianum and S. aongstroemii. Within that clade, S. wulfianum and $S$. aongstroemii were resolved as the two earliest lineages paraphyletic to a monophyletic Acutifolia s.s. The current classification in which the subgenus Acutifolia includes all these taxa, with sections for $S$. wulfianum and $S$. aongstroemii, reflects the monophyly of the broader Acutifolia but also the morphological distinctions between sections Polyclada, Insulosa, and Acutifolia. Subgenus Squarrosa is sister to this inclusive subgenus Acutifolia.

Order Sphagnales M. Fleisch., Die Musci der Flora von Buitenzorg 1: xxiii. 1904.

Family Sphagnaceae Dumort., Analyze des Familles de Plantes 68. 1829.

Genus Sphagnum L., Species Plantarum 1106. 1753. (type: S. palustre L.)
Subgenus Sphagnum L. (type: S. palustre L.)

Subgenus Rigida (Lindb.) A. Eddy, Bulletin of the British Museum (Natural History), Botany 5: 431. 1977.

Subgenus Cuspidata Lindb., Musci Scandinavici 11. 1879.

Subgenus Subsecunda (Lindb.) A. J. Shaw, comb. \& stat nov. Basionym: Sphagnum section Subsecunda Lindb., Öfversigt af Förhandlingar: Kongl. Svenska Vetenskaps-Akademien 19: 135.1862.

Subgenus Squarrosa (Russow) A. J. Shaw, comb. \& stat nov. Basionym: Sphagnum subsection Squarrosa Russow, Archiv für die Naturkunde Liv-, Ehst- und Kurlands, Serie 2, Biologische Naturkunde 7: 111, 140. 1865.

Subgenus Acutifolia (Russow) A. J. Shaw, comb. \& stat nov. Basionym: Sphagnum subsection Acutifolia Russow, Archiv für die Naturkunde Liv-, Ehst- und Kurlands, Serie 2, Biologische Naturkunde 7: 111, 114. 1865.

Section Acutifolia (Russow) Schimp., Synopsis Muscorum Europaeorum, Ed. 2, 825. 1876.

Section Polyclada Warnst., Botanical Gazette 15: 225. 1890.

Section Insulosa Isov., Annales Botanici Fennici 3: 231. 1966.

Family Flatbergiaceae, A. J. Shaw, fam. nov.

Plantae capituliis apicalibus, ramificatione fasciculata, foliis caulis cuspidatis, cellulis folii efibrillosis poris singularibus. Type: Flatbergium.

Genus Flatbergium A. J. Shaw, gen. nov. Syn.: Sphagnum subgenus Homophylla Lindb., Öfversigt af Förhandlingar: Kongl. Svenska Vetenskaps-Akademien 19: 134. 1862. (Lectotype, designated here: S. sericeum Müll. Hal.), non Homophyllum Merino, Anales de la Sociedad Española de Historia Natural 1898: 108. 1898 (Blechnaceae); Sphagnum subsect. Sericea Warnst., Sphagnum sect. Sericea (Warnst.) M. Fleisch., nom. inval.

Latin diagnosis provided by Lindberg, Öfversigt af Förhandlingar: Kongl. Svenska Vetenskaps-Akademien 19: 134. 1862. With one species: Flatbergium sericeum (Müll. Hal.) A. J. Shaw, comb nov. Basionym: Sphagnum sericeum Müll. Hal., Botanische Zeitung (Berlin) 5: 481, 484. 1847.

Family Ambuchananiaceae Seppelt \& H. A. Crum ex A. J. Shaw, fam. nov.

Plantae heterogeneae in morphologia, synapomorphis molecularibus in DNA nuclei mitochondri et plasti unitae. Type: Ambuchanania.

Genus Ambuchanania Seppelt \& H. A. Crum ex A. J. Shaw, gen. nov.

Latin diagnosis provided by H. A. Crum \& R. D. Seppelt, Contributions from the University of Michigan Herbarium 22: 29. 1999. Type: Ambuchanania leucobryoides (T. Yamag., Seppelt \& Z. Iwats.) Seppelt \& H. A. Crum ex A. J. Shaw, comb. nov. Basionym: Sphagnum leucobryoides T. Yamag., Seppelt \& Z. Iwats., Journal of Bryology 16: 45, f. 1-6. 1990.

With one species: A. leucobryoides.

Genus Eosphagnum A. J. Shaw, gen. nov.

Plantae capituliis et ramificatione fasciculata, caulibus cortice unistratosis, cortice caulium et ramorum efibrilloso, cellulis retortis destitutis, foliis sulco resorpto. Type: Eosphagnum inretortum (H. A. Crum) A. J. Shaw, comb. nov. Basionym: Sphagnum inretortum H. A. Crum, Bryologist 93: 283, f. 1-8. 1990. (Syn.: Sphagnum lapazense $\mathrm{H}$. A. Crum, Contributions from the University of Michigan Herbarium 23: 107. f. 1: a-d. 2001.)

Family Flatbergiaceae-This family is described to accommodate Flatbergium sericeum. Flatbergium sericeum is currently known from a broad geographic range from New Guinea 

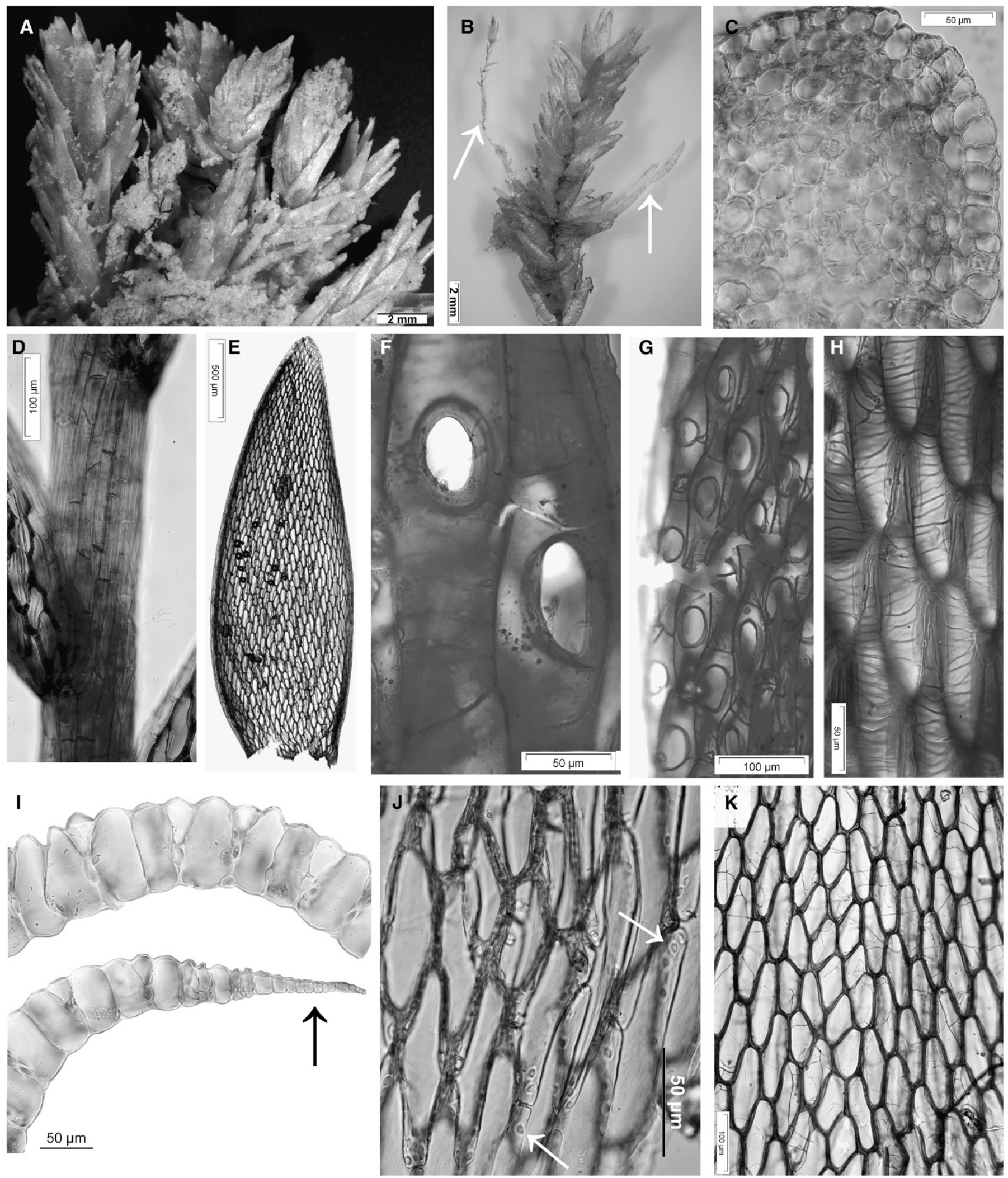

Fig. 6. Morphological characters of Ambuchanania leucobryoides (Buchanan 16981). (A) Gametophyte habit. (B) Gametophyte plant showing two branches (arrows): long branch (left) and short ranch (right). (C) Stem, transverse section. (D) Branch cortex showing absence of retort cells. (E) Stem leaf. (F) Two leaf cell pores showing raised borders, upper part of leaf on short branch. (G) Leaf cell pores, upper part of leaf on short branch. (H) Upper cells of leaf from short branch showing fibrils. (I) Stem leaf transverse sections, median (above) and marginal (below); arrow indicates differentiated leaf border. (J) Base of stem leaf, inner surface, showing very small pores (arrows). (K) Upper stem leaf cells, outer surface. All voucher specimens in DUKE. 
northward to China (Eddy, 1977; Li and He, 1999). Warnstorf (1911) classified $F$. sericeum in a group (at the subsectional level) that he called Sericea, along with the North American species, S. macrophyllum Brid. and S. cribrosum Lindb. [the latter as $S$. floridanum (Austin) Cardot]. He grouped these species together because they share the unusual feature of lacking wall fibrils in the branch and stem leaf hyaline cells. The only other species of Sphagnum that consistently lack leaf cell fibrils are S. efibrillosum A. L. Andrews and S. novae-caledoniae Paris \& Warnst., both endemic to New Guinea. Eddy (1977) and Crum (1992) classified both S. efibrillosum and S. novae-caledoniae in the section Subsecunda, but considered S. macrophyllum and $S$. cribrosum as belonging to a different section, Isocladus. More recent phylogenetic evidence demonstrates (with strong support from multiple loci) that $S$. macrophyllum and $S$. cribrosum are also nested within section Subsecunda (Shaw et al., 2004); unfortunately, S. efibrillosum and S. novae-caledoniae have not been included in molecular phylogenetic analyses. The type specimen of $S$. efibrillosum (Papua New Guinea, L. J. Brass $4473 \mathrm{NY}$ !) is morphologically quite similar to $S$. macrophyllum and is likely related within the section Subsecunda.

It is clear from the current results that Flatbergium sericeum, in contrast, is not a member of section Subsecunda, which is part of the core clade of Sphagnum (Sphagnum in Fig. 1). Morphologically, $F$. sericeum has distinctive features in addition to the absence of leaf cell wall fibrils, but none that would suggest a priori that the species is outside the core group of Sphagnum species. Eddy (1977) classified it in a monospecific subgenus Homophylla of Sphagnum, based on the lack of differentiation in size and shape between the stem and branch leaves, the absence of leaf cell fibrils, and the presence of single pores near the apices of leaf hyaline cells. None of these characters alone is absolutely unique within Sphagnum, but combined, they differentiate $F$. sericeum from any of the traditionally recognized sections. In transverse section, the shape of the branch leaf chlorophyllose cells, generally diagnostic for different sections of Sphagnum, are compatible with a placement for $F$. sericeum in the section Subsecunda. Eddy (1977) noted that the stem anatomy of F. sericeum is similar to species in the section Cuspidata. In his discussion of F. sericeum and the subgenus Homophylla, Eddy (1977) argued that the absence of leaf cell fibrils in $F$. sericeum is primitive, whereas their absence in $S$. macrophyllum, S. cribrosum, and S. novae-caledoniae represents secondary loss(es).

Family Ambuchananiaceae-When Crum and Seppelt (1999) segregated Sphagnum leucobryoides in its own genus, family, and order (Ambuchanania, Ambuchananiaceae, Ambuchananiales, respectively), they provided a single Latin diagnosis, which makes these names nomenclaturally invalid. Seppelt (2000) attempted to validate the Ambuchananiaceae, but because the genus name was still invalid, the family name also remained invalid. We here validate Ambuchanania (above). We choose not to separate the Ambuchananiaceae in a separate order distinct from the Sphagnales.

Both the 60-taxon, eight-locus data set and the nine-taxon, 11-locus data set provide strong support for a sister group relationship between Ambuchanania and Eosphagnum inretortum. Support for this relationship enjoys a $100 \%$ posterior probability under Bayesian inference regardless of the substitution model and mode of evolution (98\% in one analysis). Maximum likelihood support is weaker; bootstrapping provided less than $50 \%$ support in the 60 -taxon analyses, but $71 \%$ of the bootstrap replicates did resolve E. inretortum as sister to Ambuchanania in the nine-taxon analysis. Despite lackluster support for the sister-group relationship from bootstrapping in the ML analyses, Ambuchanania and $S$. inretortum were resolved as sister taxa in both optimal ML trees, as they were in all Bayesian reconstructions. The second data set was constructed in an attempt to refute the sister group hypothesis for Ambuchanania and E. inretortum after this relationship was resolved in the 60-taxon data set, but analyses with more genomic sampling provided even stronger support. When we constrained this tree to a topology with Ambuchanania sister to all other species of Sphagnopsida (including $F$. sericeum and $E$. inretortum), the constrained topology was significantly less likely than the unconstrained tree that resolved Ambuchanania and E. inretortum as sister taxa. We conclude that this relationship is accurate. For this reason, we classify Ambuchanania (with A. leucobryoides) and Eosphagnum (with E. inretortum) in the same family, Ambuchananiaceae.

Genus Eosphagnum-Eosphagnum inretortum conforms to "mainstream" Sphagnum architecture at the whole-plant level, with terminal capitula, typical anatomy of stems and branches, fasciculate branching, and dimorphic leaf cells with the hyaline cells ornamented by pores and wall fibrils. The branch cortex lacks retort cells, but these are lacking in other Sphagnum species scattered across the genus. Differentiated retort cells are lacking in the sections Sphagnum and Rigida within the core clade of Sphagnum, although the cortical cells commonly have pores. In S. macrophyllum and S. cribrosum (section Subsecunda), the branches lack retort cells and cortical cells are aporose, very similar to those found in E. inretortum. Clearly, details of cortical cell morphology are labile within Sphagnum.

When he described Sphagnum (Eosphagnum) inretortum as a new species (as S. lapazense), Crum (2001a, p. 107) stated, "Because of the cucullate leaves with resorption furrows at the margins, the species clearly belongs in the section Sphagnum, although the leaves lack membrane gaps at the back of the apex and fibrils in the stem and branch cortex." The elliptical shape of branch leaf chlorophyllose cells in transverse section is consistent with a placement in section Sphagnum, as are the large size and limited number of branch leaf pores.

Despite a superficial similarity to species of section Sphagnum, Eosphagnum inretortum has features inconsistent with that section. The stem cortex of section Sphagnum species is differentiated as 3-4 layers of enlarged hyaline cells, whereas the cortex in E. inretortum consists of a single layer of enlarged cells. Branch leaves of species in section Sphagnum are cucullate and have extensive resorption of cell walls on the outer convex surfaces near the leaf apices (the membrane pleats mentioned by Crum, 2001a); these features are both absent in E. inretortum. Crum (1990) cited this absence of resorption when he excluded E. inretortum from the section Sphagnum, but trivialized the difference when he chose to classify S. lapazense within the section Sphagnum 11 yr later (Crum, 2001a). Moreover, E. inretortum lacks fibrils in the stem and branch cortical cells, a feature characteristic of, though somewhat variable within, the section Sphagnum. Some species of the section do have the fibrils weakly developed, rudimentary, or virtually absent, but there is no hint of cortical cell fibrils in E. inretortum. The combination of morphological traits characterizing E. inretortum would seem to exclude the species from placement in any known section of Sphagnum. Some morphologically aberrant species (e.g., S. macrophyllum; S. pylaesii Brid.) nevertheless appear to be phylogenetically nested within larger sections and the same could be true for E. inretortum. However, molecular data presented 
in Shaw et al. (2003) and strongly corroborated here, demonstrate unambiguously that E. inretortum has no close relationship to the section Sphagnum or to the genus Sphagnum

The species-level taxonomy of the genus Eosphagnum, which we currently consider to be monospecific, may need to be revisited in the future. We recognize a single species, E. inretortum, despite a level of variation in leaf pore structure that might in some cases distinguish different species in Sphagnum. Crum's (2001a) original protologue of S. lapazense was confused because his written description did not match his illustrations. In the text, he described the branch leaves in the type of $S$. lapazense as having few or no pores on the outer convex surfaces, with 4-9 round pores on the inner surfaces. This description agrees with our observations on the type collection (Price 1236). His illustrations, however, are reversed; his fig. 1b (Crum, 2001a) shows cells with round pores but is labeled as from the outer surface, and fig. 1c, labeled as the inner surface, shows cells with no pores. The latter shows the characteristic striations found on the outer surfaces of hyaline cells in all three collections of E. inretortum (illustrated in the current paper as Fig. 5G-I).

In contrast to the type of Sphagnum lapazense, the Chilean collection that we currently attribute to Eosphagnum inretortum has branch leaves with more conspicuous pores on the outer surfaces than on the inner surfaces (matching Crum's illustrations of S. lapazense, though not his description of that species)! In pore structure, the type of E. inretortum is intermediate between the Chilean collection and the type of S. lapazense, providing evidence that the differences among plants represent conspecific variation. Moreover, the Bolivian (S. lapazense) and Chilean samples were identical across the 11705 nucleotides included in the nine-taxon, 11-locus data set. They do differ at one site in a variable part of the ITS (nrDNA) locus that was excluded from the formal analyses because it could not be aligned across all nine taxa.

Genus Ambuchanania-When they first described A. leucobryoides, Yamaguchi et al. (1990) placed the species in a new section, Buchanania, of the genus Sphagnum. Crum and Seppelt (1999) reviewed the morphological features that set this species apart from other peat mosses and elevated the section to generic rank as Ambuchanania (because at the generic level the name Buchanania is preoccupied). Two genera have been segregated from Sphagnum over the years (i.e., Isocladus Lindb. for S. macrophyllum, Hemitheca (Lindb. ex Braithw.) Lindb., an invalid name proposed provisionally by Lindberg (1882) for S. pylaesii). However, neither of these segregate genera has been widely accepted.

Ambuchanania leucobryoides is far more distinct morphologically from any other species of Sphagnum than is S. macrophyllum or S. pylaesii. Unique morphological characteristics of A. leucobryoides were described in detail by Yamaguchi et al. (1990) and summarized by Crum and Seppelt (1999). The gametophytes are simple or sparsely and irregularly branched, a feature that is shared with some other species of Sphagnum, especially in the section Subsecunda. However, more significant than the difference in overall gametophyte architecture characterizing Ambuchanania are numerous unique anatomical features. The stem of Ambuchanania consists of more or less uniform cells with no differentiation of wood cylinder or enlarged cortical cells. Moreover, the leaves of Ambuchanania are partially bistratose and have a conspicuous border of linear cells, features with no counterparts in other Sphagnum species. The leaf cells are dimorphic, with chlorophyllose and hyaline cells, but the arrangement of the two cell types is unlike that of any Sphagnum species, and although leaf development has not been documented in Ambuchanania, it is clear from the arrangement of hyaline and chlorophyllose cells that leaf ontogeny departs significantly from the regular pattern described for Sphagnum (Holcombe, 1984). Lateral branches in Ambuchanania are uncommon and are of two more or less distinct types: short and long branches (Yamaguchi et al., 1990). The leaves of these branch types differ in size, shape, and cellular anatomy. Pores and fibrils, both hallmarks of sphagnoid mosses, are better developed on the leaves of short branches.

As in Sphagnum, the sporophyte of Ambuchanania lacks a seta, and the capsule is instead raised on a pseudopodium of gametophytic origin. The sporophytes of Ambuchanania do not appear to differ in any significant way from those of Sphagnum and are presumed to share similar embryological features that distinguish Sphagnum from other mosses. The origin of sporogenous tissue from amphithecial rather than endothecial cells, as in other species of Sphagnopsida, is presumed to characterize Ambuchanania, although this needs to be confirmed. Ambuchanania has bisexual gametophytes and archegonia are borne in terminal clusters with the antheridia situated at the base of these clusters (Yamaguchi et al., 1990). Sphagnum can have uni- or bisexual gametophytes, and the perichaetia (archegonia and surrounding leaves), in contrast to Ambuchanania, are not terminal on the main stem but are rather on short branches near the stem apices. The antheridia are produced on catkin-like branches in the capitula well removed from the perichaetia in Sphagnum species with bisexual gametophytes. The antheridia of Ambuchanania are oblong-elliptical, similar to those of other mosses but unlike the globose antheridia of all Sphagnum species.

\section{Implications of Sphagnopsida phylogeny for morphologi-} cal evolution-Although the relative timing of phylogenetic branching among the three major clades of Sphagnopsida is unresolved, the sister-group relationship between Eosphagnum and Ambuchanania implies that the simple and highly divergent gametophyte morphology of Ambuchanania is derived rather than primitive. Regardless of whether Flatbergium sericeum diverged first and the Ambuchanania plus Eosphagnum clade is sister to the core Sphagnum clade, or Ambuchanania plus Eosphagnum diverged first, our phylogenetic results favor the interpretation that Ambuchanania evolved from an ancestor that had "mainstream" Sphagnum architecture, i.e., fasciculate branching, a terminal capitulum, and dimorphic leaf cells comprising unistratose leaves. Although both Ambuchanania and $E$. inretortum lack retort cells in the cortex of branches, $F$. sericeum has well-developed and typical retort-shaped cortical cells. It is currently ambiguous from our phylogenetic results whether the absence of retort cells in the Ambuchanania plus Eosphagnum clade represent a loss or plesiotypic absence. Our results are also ambiguous with regard to whether the absence of leaf cell fibrils in F. sericeum is derived or plesiotypic.

The positions and morphology of gametangia in Ambuchanania have weighed heavily in arguments that the species should be segregated from Sphagnum into its own genus, family, and order of Sphagnopsida (Crum and Seppelt, 1999; or in its own section of Sphagnum: Yamaguchi et al., 1990). The gametophytes are bisexual, but unlike bisexual species of Sphagnum, archegonia are terminal on the stems rather than on short lateral branches produced near the stem apices, and antheridia are borne at the bases of the perichaetia rather than on specialized branches of the capitula. Antheridia of Ambuchanania are elongate like 
those found in other mosses, whereas antheridia are globose in all Sphagnum species from which they have been described (unknown in a few). The antheridia of Flatbergium sericeum are globose and therefore typically sphagnoid. The type specimen of $S$. lapazense bears no sporophytes or gametangia, but the type of Eosphagnum inretortum and the population from Chile had sporophytes when they were collected. Nevertheless, antheridia could not be located among plants from either locality. Most species of Sphagnum produce antheridia 6 months or more before they form mature sporophytes, so it is not surprising that both sporophytes and antheridia did not occur in the same collections. If it turns out that E. inretortum has typical round sphagnoid antheridia, it would imply that elongate antheridia is an autapomorphy for Ambuchanania. If on the other hand, E. inretortum has elongate antheridia, the evolution of this trait would remain ambiguous. The elongate antheridia of Ambuchanania might be a plesiomorphic trait retained from an ancestor in common with the Takakiopsida, or it could be a synapomorphy for the Ambuchanania plus Eosphagnum clade. The likelihood of these two alternative scenarios would depend on the relative branching order of Flatbergiaceae, Ambuchananiaceae, and Sphagnaceae.

Timeframe of diversification in the Sphagnopsida-Shaw et al. (2010) estimated divergence times from the phylogeny shown in Fig. 1 based on a relaxed clock model using Bayesian methods implemented in BEAST (Drummond and Rambaut, 2007), calibrated with estimated substitution rates of nuclear, plastid, and mitochondrial loci. Their estimates, albeit crude, suggest that the Sphagnopsida is an ancient group and diverged from the Takakiopsida between 129 and 319 million years ago (Ma), and the Flatbergiaceae plus Ambuchananiaceae diverged from the Sphagnaceae between 34 and $104 \mathrm{Ma}$. The diversification of extant Sphagnum species, in contrast, occurred relatively recently, between seven and $20 \mathrm{Ma}$, possibly associated with climatic cooling of the northern hemisphere and origin of boreal vegetation during the Miocene (Shaw et al., 2010).

The fossil record for Sphagnum and Sphagnopsida is very limited but what is known does not contradict this chronology. The earliest fossils attributed to the group belong to the Permian genus Protosphagnum (Neuberg, 1960). Protosphagnum is said to have a leaf midrib (unlike any extant Sphagnum), although the evidence based on photographs is not overly convincing. The species does appear to have dimorphic leaf cells. The arrangement of putative hyaline and chlorophyllose cells in Protosphagnum was interpreted by Butterfass (1992) in relation to the development of dimorphic cells in extant species, and it appears that the patterns of cell divisions may be similar. Actual developmental sequences for leaves of Protosphagnum are, of course, not known. A few other Paleozoic species of Sphagnopsida have been described but assigned to genera other than Sphagnum; leaves and spores that appear to represent Sphagnum are known from the Mesozoic and Teriary (reviews in Lacey, 1969; Oostendorp, 1987)

If the divergence of Ambuchanania and Eosphagnum was some $50 \mathrm{Ma}$ as implied by that chronology, it is perhaps less surprising that the two relictual species differ so greatly in morphology. The long branches separating early-diverging lineages within the Sphagnopsida (Flatbergium, Ambuchanania, Eosphagnum), and separating these lineages from Sphagnum s.s., suggest that extensive extinction of other early-diverging taxa might have occurred. By comparison, if we consider morphological diversity among extant species within
Sphagnum and imagine what levels of morphological disparity might look like if phylogenetically intermediate species were currently extinct, comparable patterns could occur. The morphological disparity between E. inretortum and A. leucobryoides could reflect extinction of other related species over the last ca. 50 Myr since the Ambuchananiaceae diverged from the Flatbergiaceae.

Relationship of Sphagnopsida to other classes of phylum Bryophyta-Several previous molecular analyses (e.g., Newton et al., 2000; Nickrent et al., 2000; Cox et al., 2004; Qiu et al., 2006) have resolved Takakia as sister to Sphagnum, though rarely with high bootstrap support. That sister-group relationship was also resolved by all analytical models we employed for the 60-taxon, eight-locus data set presented here. The ML and homogeneous Bayesian analyses provided strong support for a Takakia plus Sphagnum clade (95\% and 91\% bootstrap support in online Appendix S1, supplemental Figs. S.1.17 and S.1.18, 1.0 posterior probability in Fig. S.1.19). But when the polytomy prior was added to the Bayesian analysis (Fig. S.1.20) the posterior probability dropped to 0.92 , and when composition was modeled across the tree (Appendix S1: Figs. S.1.21, S.1.22--S.1.28), support disappeared completely. These results suggest that support for the Takakia plus Sphagnopsida clade may be due to a phylogenetic artifact caused by nonstationary composition bias.

Morphological characters suggest a closer relationship of Takakia to Andreaea and/or Andreaeobryum than to Sphagnum (Murray, 1988; Renzaglia et al., 1997). However, at least some such similarities may be plesiotypic within the mosses (for example, effects [or lack thereof] of calyptrae on normal capsule development, restriction of placental transfer cells to the sporophyte tissue, absence of sporophytic conducting cells [Renzaglia et al., 1997]) and are therefore uninformative with regard to relationships among groups. A critical feature is the embryological origins of the sporogenous tissue of sporophytes derived from the endothecium in Andreaea, Andreaeobryum, and bryopsid mosses, but from the amphithecium in Sphagnum. Origin of the sporogenous tissue in Takakia is not known, though anatomical features of mature sporophytes suggest that is may be endothecial.

Overall, Takakia and species of Sphagnopsida are extremely different in morphology, but Takakia is also very different from Andreaea, Andreaeobryum, or any other moss. If phylogenetic reconstructions that resolve Sphagnopsida plus Takakia as sister to a clade containing Andreaea, Andreaeobryum, and the rest of the (bryopsid) mosses, a classification of phylum Bryophyta with two subphyla would best reflect history. This would provide an alternative hypothesis to that of Stech and Frey (2008) in which three groups of equal rank are recognized (Takakiophytina, Sphagnophytina, Bryophytina), or that of Goffinet et al. (2009) in which five groups are distinguished (Sphagnopsida, Takakiopsida, Andreaeobryopsida, Andreaeopsida, Bryopsida).

\section{LITERATURE CITED}

Andrews, A. L. 1911. Notes on North American Sphagnum. I. The groups. Bryologist 14: 72-75.

Beckert, S., S. Steinhauser, H. Muhle, and V. Knoop. 1999. A molecular phylogeny of the bryophytes based on nucleotide sequences of the mitochondrial nad5 gene. Plant Systematics and Evolution 218: 179-192.

Bennett, M. D., And I. J. Leitch. 2005. Plant DNA C-values database (release 4.0, October 2005). Website http://data.kew.org/cvalues/. 
BollBaCK, J. P. 2002. Bayesian model adequacy and choice in phylogenetics. Molecular Biology and Evolution 19: 1171-1180.

Bower, F. O. 1935. Primitive land plants. Macmillan, London, UK.

Butterfass, T. 1992. The patterns of cell division and chloroplast reproduction in young leaflets of Sphagnum. Journal of Bryology 17: $143-153$.

Campbell, D. H. 1895. The structure and development of mosses and ferns (Archegoniatae). Macmillan and Co., London, UK

Cavers, F. 1911. The inter-relationships of the Bryophyta. New Phytologist reprint 4. Botany School, Cambridge, UK.

Cox, C. J., P. G. Foster, R. P. Hirt, S. R. Harris, and M. T. Embley. 2008. The archaebacterial origins of eukaryotes. Proceedings of the National Academy of Sciences, USA 105: 20356-20361.

Cox, C. J., B. Goffinet, A. E. Newton, A. J. Shaw, and T. A. J. Hedderson. 2000. Phylogenetic relationships among the diplolepideous-alternate mosses (Bryidae) inferred from nuclear and chloroplast DNA sequences. The Bryologist 103: 224-240.

Cox, C. J., B. Goffinet, A. J. Shaw, and S. Boles. 2004. Phylogenetic relationships among the mosses based on heterogeneous Bayesian analysis of multiple genes from multiple genomic compartments. Systematic Botany 29: 234-250.

Cox, C. J., And T. A. J. Hedderson. 1999. Phylogenetic relationships among the ciliate arthrodontous mosses: Evidence from chloroplast and nuclear DNA sequences. Plant Systematics and Evolution 215: 119-139.

Crosby, M. R., R. E. Magill, B. Allen, and S. He. 2000. A checklist of the mosses. Missouri Botanical Garden, St. Louis, Missouri, USA. Website http://www.mobot.org/MOBOT/tropicos/most/checklist.shtml.

Crum, H. A. 1984. Sphagnopsida, Sphagnaceae. North American Flora, series 2, part 11, 1-180. New York Botanical Garden, New York, New York, USA.

Crum, H. A. 1990. Sphagnum inretortum, a new species in a new section from Bolivia. Bryologist 93: 283-285.

Crum, H. A. 1992. Miscellaneous notes on the genus Sphagnum. 1-2. Bryologist 95: 274-279.

Crum, H. A. 2001a. Miscellaneous notes on Sphagnum-11. Contributions from the University of Michigan Herbarium 23: 107-114.

Crum, H. A. 2001b. Structural diversity of bryophytes. University of Michigan Herbarium, Ann Arbor, Michigan, USA.

Crum, H. A., And R. D. Seppelt. 1999. Sphagnum leucobryoides reconsidered. Contributions from the University of Michigan Herbarium 22: $29-31$.

Doležel, J., J. Bartoš, H. Voglmayr, and J. Greilhuber. 2003. Nuclear DNA content and genome size of trout and human. Cytometry 51A: $127-128$

DRUmmond, A. J., AND A. Rambaut. 2007. BEAST: Bayesian evolutionary analysis by sampling trees. BMC Evolutionary Biology 7: 214

Duckett, J. G., S. Pressel, K. N. Y. P'NG, And K. S. RenZaglia. 2009. Exploding a myth: The capsule dehiscence mechanism and function of pseudostomata in Sphagnum. New Phytologist 183: 1053-1063.

EDDY, A. 1977. Sphagnales of tropical Asia. Bulletin of the British Museum (Natural History). Historical Series 5: 359-445.

Edgar, R. C. 2004. MUSCLE: Multiple sequence alignment with high accuracy and high throughput. Nucleic Acids Research 32: 1792-1797.

FleisCher, M. 1923. Allgemeine Uebersicht des natürlichen Systems der Laubmoose. In Die Moose der Flora von Buitenzorg 4: XI-XXIII. E. J. Brill, Leiden, Netherlands.

Foster, P. 2004. Modeling compositional heterogeneity. Systematic Biology 53: 485-495.

FRITSCH, R. 1982. Index to plant chromosome numbers-Bryophyta. Scheltema and Holkema, Boston, Massachusetts, USA.

Galtier, N., M. Gouy, and C. Gautier. 1996. SEA VIEW and PHYLO_ WIN: Two graphic tools for sequence alignment and molecular phylogeny. CABIOS 12: 543-548.

Garbary, D. J., K. S. Renzaglia, and J. G. Duckett. 1993. The phylogeny of land plants: A cladistic analysis based on male gametogenesis. Plant Systematics and Evolution 188: 237-269.

Goffinet, B., W. R. BuCK, AND A. J. Shaw. 2009. Morphology, anatomy, and classification of the Bryophyta. In B. Goffinet and A. J. Shaw [eds.], Bryophyte biology, 2nd ed., 55-138. Cambridge University Press, New York, New York, USA.

Goffinet, B., C. J. Cox, A. J. Shaw, And T. A. J. Hedderson. 2001. The Bryophyta (mosses): Systematic and evolutionary inferences from an rps4 gene (cpDNA) phylogeny. Annals of Botany 87: 191-208.

Greilhuber, J., AND I. EBert. 1994. Genome size variation in Pisum sativum. Genome 37: 646-655.

HaECKel, E. 1876. The history of creation, vol. 2., Appelton, New York, New York, USA.

Hedderson, T. A., R. L. Chapman, and W. L. Rootes. 1996. Phylogenetic relationships of bryophytes inferred from nuclear encoded rRNA gene sequences. Plant Systematics and Evolution 200: 213-224.

Holcombe, J. W. 1984. Morphogenesis of branch leaves of Sphagnum magellanicum Brid. Journal of the Hattori Botanical Laboratory 57: 179-240.

Isovirta, P. 1966. Studies on Sphagnum L. 1. Nomenclatural revision of the European taxa. Annales Botanici Fennici 3: 199-264.

Johnson, K. A., J. Whinam, A. M. Buchanan, and J. Balmer. 2008. Ecological observations and new locations of a rare moss, Ambuchanania leucobryoides. Papers and Proceedings of the Royal Society of Tasmania 142: 79-84.

Karlin, E. F., S. B. Boles, M. Ricca, E. M. Temsch, J. Grelihuber, AND A. J. SHaw. 2009. Three genome mosses: Complex double allopolyploid origins for triploid gametophytes in Sphagnum. Molecular Ecology 18: 1439-1454.

Kenrick, P., and P. R. Crane. 1997. The origin and early diversification of land plants: A cladistic study. Smithsonian Institution Press, Washington, D.C., USA.

LACEY, W. S. 1969. Fossil bryophytes. Biological Reviews of the Cambridge Philosophical Society 44: 189-205.

Lartillot, N., AND H. A. PhilipPe. 2004. Bayesian mixture model for across-site heterogeneities in the amino-acid replacement process. Molecular Biology and Evolution 21: 1095-1109.

Lewis, P. O., M. Holder, AND K. E. Holsinger. 2005. Polytomies and Bayesian phylogenetic inference. Systematic Biology 54: 241-253.

LI, X.-J., AND S. He. 1999. Sphagnaceae. In C. Chen, M. R. Crosby, and S. He [eds.]. Moss flora of China, vol. 1, 3-48. Missouri Botanical Garden, St. Louis, Missouri, USA.

Ligrone, R., AND J. G. Duckett. 1998. Development of the leafy shoot in Sphagnum (Bryophyta) involves the activity of both apical and subapical meristems. New Phytologist 140: 581-595.

Ligrone, R., J. G. Duckett, and K. S. Renzaglia. 1993. The gametophyte-sporophyte junction in land plants. Advances in Botanical Research 19: 231-317.

LiNDBERG, S. O. 1882. Europas och Nord Amerikas hvitmossor (sphagna). J. C. Frenckell, Helsinki, Finland.

Mishler, B. D., AND S. P. Churchill. 1984. A cladistic approach to the phylogeny of the "bryophytes". Brittonia 36: 406-424

Murray, B. M. 1988. Systematics of the Andreaeopsida (Bryophyta): Two orders with links to Takakia. Beihefte zur Nova Hedwigia 90: 289-336.

NeubERG, M. F. 1960. Leafy mosses from the Permian deposits of Angarida. Trudy Geological Institute, Leningrad 19: 1-104 [in Russian].

Newton, A. E., C. J. Cox, J. G. Duckett, J. A. Wheeler, B. Goffinet, T. A. J. Hedderson, AND B. D. Wheeler. 2000. Evolution of the major moss lineages: Analyses based on multiple genes sequences and morphology. Bryologist 103: 187-211.

Newton, M. A., AND A. E. Raftery. 1994. Approximate Bayesian inference with the weighted likelihood bootstrap. Journal of the Royal Statistical Society, B, Methodological 56: 3-48.

Nickrent, D. L., C. L. Parkinson, J. D. Palmer, and R. J. Duff. 2000 Multigene phylogeny of land plants with special reference to bryophytes and the earliest land plants. Molecular Biology and Evolution 17: $1885-1895$.

Nishiyama, T., P. G. Wolf, M. Kugita, R. B. Sinclair, M. Sugita, C. Sugiura, T. Wakasugi, et al. 2004. Chloroplast phylogeny indicates that bryophytes are monophyletic. Molecular Biology and Evolution 21: 1813-1819. 
Nylander, J. A. A. 2004. MrModeltest v2. Program distributed by the author. Evolutionary Biology Centre, Uppsala University, Uppsala, Sweden.

OostendoRP, C. 1987. The bryophytes of the Palaeozoic and the Mesozoic. Bryophytorum Bibliotheca 34. J. Cramer, Berlin, Germany.

Qiu, Y.-L., Y. Cho, J. C. Cox, AND J. D. Palmer. 1998. The gain of three mitochondrial introns identifies liverworts as the earliest land plants. Nature 394: 671-674.

Qiu, Y.-L., L. Li, B. Wang, Z. Chen, V. Knoop, M. Groth-Malonek, O. DOMBrovsKa, ET AL. 2006. The deepest divergences in land plants inferred from phylogenomic evidence. Proceedings of the National Academy of Sciences, USA 103: 15511-15516.

Renzaglia, K. S., K. D. McFarland, and D. K. Smith. 1997. Anatomy and ultrastructure of the sporophyte of Takakia ceratophylla (Bryophyta). American Journal of Botany 84: 1337-1350.

Ricca, M., F. W. Beecher, S. B. Boles, E. Temsch, J. Greilhuber, E. Karlin, AND A. J. Shaw. 2008. Cytotype variation and allopolyploidy in North American species of the Sphagnum subsecundum complex. American Journal of Botany 95: 1606-1620.

Rodríguez-Ezpeleta, N., H. Philippe, H. Brinkmann, B. Becker, And M. Melkonian. 2007. Phylogenetic analyses of nuclear, mitochondrial, and plastid multigene data sets support the placement of Mesostigma in the Streptophyta. Molecular Biology and Evolution 24: 723-731.

Ronquist, F., AND J. P. HuELSENBECK. 2003. MrBayes 3: Bayesian phylogenetic inference under mixed models. Bioinformatics 19: 1572-1574.

Schofield, W. B. 1985. Introduction to bryology. Macmillan, New York, New York, USA.

SePPELT, R. D. 2000. The Sphagnopsida (Sphagnaceae; Ambuchananiaceae) in Australia. Hikobia 13: 163-183.

Shaw, A. J., C. J. Cox, And S. B. Boles. 2005. Phylogeny, species delimitation, and interspecific hybridization in Sphagnum section Acutifolia. Systematic Botany 30: 16-33.

Shaw, A. J., N. Devos, C. J. Cox, S. B. Boles, B. Shaw, A. M. Buchanan, L. Cave, and R. Seppelt. 2010. Peatmoss (Sphagnum) diversification associated with Miocene Northern Hemisphere climatic cooling? Molecular Phylogenetics and Evolution 55: $1139-1145$.

Shaw, A. J., AND K. S. RenZaglia. 2004. Phylogeny and diversification of bryophytes. American Journal of Botany 91: 1557-1581.

Shaw, J. 2000. Phylogeny of the Sphagnopsida based on nuclear and chloroplast DNA sequences. Bryologist 103: 277-306.
Shaw, J., C. J. Cox, AND S. B. Boles. 2003. Polarity of peatmoss (Sphagnum) evolution: Who says mosses have no roots? American Journal of Botany 90: 1777-1787.

Shaw, S., C. J. Cox, AND S. B. Boles. 2004. Phylogenetic relationships among Sphagnum sections, Hemitheca, Isocladus, and Subsecunda. Bryologist 107: 189-196.

Stamatakis, A. 2006. RAxML-VI-HPC: Maximum likelihood-based phylogenetic analyses with thousands of taxa and mixed models. Bioinformatics 22: 2688-2690.

Stamatakis, A., P. Hoover, AND J. Rougemont. 2008. A rapid bootstrap algorithm for the RAxML web servers. Systematic Biology 57: 758-771.

Stech, M., AND W. Frey. 2008. A morpho-molecular classification of the mosses (Bryophyta). Nova Hedwigia 86: 1-21.

Steere, W. C. 1958. Evolution and speciation in mosses. American Naturalist 92: 5-20.

SwofFord, D. L. 1998. PAUP*: Phylogenetic analysis using parsimony (*and other methods). Sinauer, Sunderland, Massachusetts, USA.

Temsch, E. M., J. Greilhuber, and R. Krisai. 1998. Genome size in Sphagnum (peat moss). Botanica Acta 111: 325-330.

Temsch, E. M., J. Greilhuber, and R. Krisai. 2010. Genome size in liverworts. Preslia 82: 63-80.

Terasawa, K., M. Odahara, Y. Kabeya, T. Kikugawa, Y. Sekine, M. Fujiwara, and N. Sato. 2007. The mitochondrial genome of the moss Physcomitrella patens sheds new light on mitochondrial evolution in land plants. Molecular Biology and Evolution 24: 699-709.

VANDERPOORTEN, A., AND B. GofFinet. 2009. Introduction to bryophytes. Cambridge University Press, Cambridge, UK.

VitT, D. H. 1984. Classification of the Bryopsida. In R. M. Schuster [ed.], New manual of bryology, vol. 2, 676-759. Hattori Botanical Laboratory, Nichinan, Japan.

Voglmayr, H. 2000. Nuclear DNA amounts in mosses (Musci). Annals of Botany 85: 531-546.

Wahrmund, U., D. Quandt, AND V. Knoop. 2010. The phylogeny of mosses - addressing open issues with a new mitochondrial locus: group I intron cobi420. Molecular Phylogenetics and Evolution 54: 417-426.

WARnStORF, C. 1911. Sphagnales-Sphagnaceae (Sphagnologia Universalis) In H. G. A. Engler [ed.], Das Pflanzenreich, Heft 51. Engelmann, Leipzig, Germany.

Yamaguchi, T., R. D. Seppelt, Z. Iwatsuki, and A. M. Buchanan. 1990. Sphagnum (section Buchanania) leucobryoides sect. et sp. nov. from Tasmania. Journal of Bryology 16: 45-64. 
APPENDIX 1. Accession information and GenBank numbers for samples included in phylogenetic analyses of the Sphagnopsida. A dash (-) means a sequence was not obtained. Herbarium acronyms: DUKE $=$ Duke University, MICH = University of Michigan, NY = New York Botanical Garden, RNG = University of Reading.

Taxon; Isolate number; GenBank accessions: rps4, trnL, psbA, nuc18S, nuc26S-1, nuc26S-2, rbcL, nad5, nad7, trnG; Voucher specimen, Herbarium.

Alophosia azorica (Renauld \& Cardot) Cardot; MDP332; AY330476, AY312891, 一, AY330424, GQ368591, AY312924, AY312867, AY330453, GQ368647; Rumsey s.n.; DUKE. Ambuchanania leucobryoides Seppelt \& H.A. Crum; SB3269; GQ368612, GQ368649, GQ368606, GQ375079, GQ375083, GQ368584, GQ368609, GQ368600, GQ368603, GQ368615; Buchanan s.n; DUKE. Andreaea wilsonii Hook. f.; B75; AY330477, AY312939, AY312892, AY330416, AY330425, AY312925, AY312868, AY330454, —; Cox 00-668; DUKE. Andreaeobryum macrosporum Steere \& B. M. Murray; SB472; AF306953, —, AY312893, AJ275005, AY330426, —, AF231059, —, 一, -; Schofield 78094; DUKE. Aulacomnium turgidum (Wahlenberg) Schwägr.; A37; AF023809, AF023728, AY312894, AF023687, AY330427, —, AJ275180, AY312869, AY330455, —; Hedderson 6385; RNG. Bartramia stricta Brid.; E3; AF023799, AF023756, AY312895, AF023698, AY330428, GQ368570, AY312926, AY312870, AY330456, GQ368645; Longton 4871; RNG. Brachythecium salebrosum (Hoffm. ex F. Weber \& D. Mohr) Schimp.; BB86; AF143027, AF161120, AY312896, AY330417, AY330429, GQ368571, AY312927, AY312871, AY330457, GQ368646; Goffinet 4723; NY. Buxbaumia aphylla Hedw.; B759; AF306959, AF231909, AY312897, Y17603, AY330430, GQ368572, GQ368610, AY312872, —, GQ368643; Belland 16889; DUKE. Dendroligotrichum dendroides (Brid. ex Hedw.) Broth.; BG977; AF208420, AY312940, AY312898, AY330418, AY330431, GQ368573, AF208411, AY312873, AY330458, GQ368644; Goffinet 5425; DUKE. Diphyscium foliosum (Hedw.) D. Mohr; BG712; AJ251065, AF229891, AY312899, Y17765, AY330432, GQ368574, AY312928, AY312874, AY330459, GQ368642; Goffinet 4492; DUKE. Encalypta ciliata Hedw.; BG713; AF223040, AF229897, AY312900, AF223011, AY330433, GQ368575, AY312929, AY312875, AY330460, GQ368641; Schofield 98872; DUKE. Entosthodon laevis (Mitt.) Fife; BG980; AY330478, AY312941, AY312901, AY330419, AY330434, GQ368580, AY312930, AY312876, AY330461, GQ368639; Goffinet 5601; DUKE. Fissidens subbasilaris Hedw.; BG984; AF223056, AF229913, AY312902, AF223027, AY330435, GQ368581, AF231304, AY312877, AY330462, GQ368640; Goffinet 5263; DUKE. Funaria hygrometrica Hedw.; C148, AF023776, AF231175, AY312903, X74114, AY330436, GQ368582, AF005513, Z98959, AY330463, GQ368636; Cox 148; RNG. Haplomitrium hookeri (Sm.) Nees; SB475; AJ251064, AY312942, AY312904, Y19006, AY330437, GQ368583, U87072, AY608284, GQ368637; Schofield 95224; DUKE. Hedwigia ciliata (Hedw.) P. Beauv.; A31; AJ251309, AF233587, AY312905, AJ275010, AY330438, AF231073, Z98966, AY330464, GQ368638; Hedderson 11771; RNG. Hookeria lucens (Hedw.) Smith; A80; AJ251316, AF215906, AY312906, AJ243168, AY330439, GQ368588, AY312931, Z98969, AY330465, GQ368635; Cox 118; RNG. Leucobryum sp.; AV_G7; GQ368613, GQ368650, GQ368607, —, GQ375084, GQ368585, —, GQ368601, GQ368604, GQ368617; Vanderpoorten s.n.; DUKE. Mielichhoferia elongata (Hoppe \& Hornsch.) Nees \& Hornsch.; SH5; AF023793, AF023766, AY312907, AF023708, AY330440, —, AF232693, AY312878, -, GQ368634; Shaw s.n.; RNG. Mnium hornum Hedw.; C115; AF023796, AF182360, AY312908, X80985, AY330441, GQ368586, AF226820, AY312879, —, GQ368632; Cox 115; RNG. Oedipodium griffithianum (Dicks.) Schwägr.; BG656; AF306968, AF246290, AY312909, AF228668, AY330442, GQ368576, AY312932, AY312880, AY330466, GQ368633; Schofield 98670; DUKE. Orthodontium lineare Schwägr.; A79; AF023800, AF023768, AY312910, AF023697, AY330443, GQ368577, AJ275174, AY312881, AY330467, GQ368629; Hedderson s.n.; RNG. Orthotrichum lyelli Hook. \& Taylor; L16; AF023814, AF023727, AY312911, AF025291, AY330444, GQ368578, AF005536, AY312882, AY330468, GQ368630; Hedderson 5745; RNG. Pellia epiphylla (L.) Corda; B97; AY330479, _, AY312912, X80210, AF226030, —, U87085, AY608305, —, GQ368631; Risk \& Gross 12231; DUKE. Polytrichadelphus purpureus Mitt.; MDP353; AY330480, AY312943, AY312913, AY330420, 一, GQ368587, AY312933, AY312883, AY330469, GQ368626; Cox 84/01; DUKE. Polytrichum pallidisetum
Funck; BG768;AF306956, AY312944, AY312914,AY330421,AY330445, GQ368579, AY312934, AY312884, AY330470, GQ368625; Goffinet 4581; DUKE. Porella pinnata L.; BG1072; AY330481, AY312945, AY312915, AY330422, AY330446, GQ368592, U87088, AY608308, GQ368627; Goffinet 4744; DUKE. Preissia quadrata (Scop.) Nees; BG1080; AY330482, AY312946, AY312916, X80211, AY330447, GQ368589, AY312935, AY608309, —, GQ368628; Schofield 105579; DUKE. Pyrrhobryum vallis-gratiae (Hampe ex Müll. Hal.) Manuel; 11755; AF023825, AF023754, AY312917, AF023695, AY330448, GQ368593, AJ275179, AY312885, AY330471, GQ368620; Hedderson 11775; RNG. Rhodobryum giganteum (Schwägr.) Paris; 5073; AF023789, AF023737, AY312918, AF023699, AY330449, GQ368590, AJ275176, AY312886, - GQ G68621; Longton 5073; RNG. Scouleria aquatica Hook.; 5811; AF023780, AF023723, AY312919, AF023684, AY330450, GQ368599, AF226822, AY312887, AY330472, GQ368622; Hedderson 5811; RNG. Sphagnum affine Renauld \& Cardot; SB1211; AY309713, AY297996, AY309603, —, AY309504, AY313205, AY309689, AY309555, AY309579, AY309755; Long 28884; DUKE. Sphagnum angustifolium (Warnst.) C.E.O. Jensen; SB542; AY309714, AY298005, AY309604, GQ375058, AF197086, AF198021, AY309690, AY309556, AY309580, AY309756; Shaw 9639; DUKE. Sphagnum aongstroemii C. Hartman; SB412; AY309715, AF192619, AY309605, GQ375074, AF197083, AF198018, AY309691, AY309557, AY309581, AY309757; Andrus \& Flatberg 7531; DUKE. Sphagnum compactum Lam. \& DC.; SB80; AY309716, AF192578, AY309606, GQ375073, AF197069, AF198004, AY309692, AY309558, AY309582, AY309758; Shaw 9332; DUKE. Sphagnum cuspidatum Ehrh. ex Hoffm.; SB642; AY309718, AF192633, AY309608, GQ375066, AY309506, AY313206, AY309694, AY309560, AY309584, AY309760; Shaw 9327; DUKE. Sphagnum cyclophyllum Sull. \& Lesq.; SB78; AY309719, AF192562, AY309609, GQ375063, AF197067, AF198002, AY309695, AY309561, AY309585, AY309761; Shaw 8560; DUKE. Sphagnum cymbifolioides Breutel; SB127; AY309720, AF192584, AY309610, GQ375064, AF197076, AF198011, AY309696, AY309562, AY309586, AY309762; Streimann 47192; NY. Sphagnum fuscum (Schimp.) H. Klinggr.; SB571; AY309721, AY347095, AY309611, GQ375070, AF197091, AF198026, AY309697, AY309563, AY309587, AY309763; Shaw 9678; DUKE. Sphagnum inretortum H.A. Crum; SB1052; AY309722, AY298153, AY309612, GQ375081, AY309507, —, AY309698, AY309564, AY309588, AY309764; Price et al. 1236 Bolivia; MICH. Sphagnum inretortum H.A. Crum; SB3274; GQ368614, GQ368651, GQ368608, GQ375082, —, —, GQ368611, GQ368602, GQ368605, GQ368648; Andrus 11835 Chile; DUKE. Sphagnum lescurii Sull.; SB77; AY309723, AF192565, AY309613, GQ375069, AF197066, AF198001, AY309699, AY309565, AY309589, AY309765; Shaw s.n.; DUKE. Sphagnum palustre L.; SB1209; AF231892, AF192634, AY312920, Y11370, AY330451, GQ368594, AF231887, AY312888, AY330473, GQ368623; Long 28667; DUKE. Sphagnum perichaetiale Hampe; SB74; AY309724, AF192575, AY309614, GQ375078, —,AF197999, AY309700, AY309566, AY309590, AY309766; Shaw 9213; DUKE. Sphagnum portoricense Hampe; SB106; AY309725, AF192577, AY309615, GQ375062, AF197077, AF198012, AY309701, AY309567, AY309591, AY309767; Anderson 26770; DUKE. Sphagnum pulchrum (Lindb.) Warnst.; SB543; AY309726, AY298224, AY309616, GQ375067, AF197087, AF198022, AY309702, AY309568, AY309592, AY309768; Shaw 9796; DUKE. Sphagnum quinquefarium (Lindb.) Warnst.; SB576; AY309727, AF192608, AY309617, GQ375061, AF197089, AF198024, AY309703, AY309569, AY309593, AY309769; Shaw 9682; DUKE. Sphagnum recurvum P. Beauv.; SB83; AY309728, AF192569, AY309618, GQ375065, AF197072, AF198007, AY309704, AY309570, AY309594, AY309770; Shaw 9196; DUKE. Sphagnum sericeum Müll. Hal. 1; SB858; AY309717, AY298061, AY309607, GQ375072, AY309505, 一, AY309693, AY309559, AY309583, AY309759; Tan \& Harrison s.n.; DUKE. Sphagnum sericeum Müll. Hal. 2; SB1239; AY309729, AY298280, AY309619, GQ375071, AY309508, AY313207, AY309705, AY309571, AY309595, AY309771; Yamaguchi 
18926; DUKE. Sphagnum squarrosum Crome; SB1248; AY309730, AY298287, AY309620, GQ375075, AY309509, AY313208, AY309706, AY309572, AY309596, AY309772; Higuchi 40888; DUKE. Sphagnum steerei R.E. Andrus; SB367; AY309731, AF192574, AY309621, GQ375077, AF197081, AF198016, AY309707, AY309573, AY309597, AY309773; Andrus 8574; DUKE. Sphagnum strictum Sull.; SB79; AY309732, AF192585, AY309622, GQ375080, AF197068, AF198003, AY309708, AY309574, AY309598, AY309774; Shaw 9406; DUKE. Sphagnum subnitens Russow \& Warnst.; SB538; AY309733, AY298303, AY309623, GQ375059, AF197092, AF198027, AY309709, AY309575, AY309599, AY309775; Shaw 9723; DUKE. Sphagnum tenerum Sull. \& Lesq. ex Sull.; SB75; AY309734, AF192588, AY309624, GQ375060, AF197065, AF198000, AY309710, AY309576, AY309600, AY309776; Shaw 9335; DUKE. Sphagnum teres (Schimp.) Ångström; SB366; AY309735, AF192596, AY309625, GQ375076, AF197090, AF198025,
AY309711, AY309577, AY309601, AY309777; Hedderson 7928; DUKE. Sphagnum wulfianum Girgensohn; SB1288; AY309736, AY298357, AY309626, GQ375068, AY309510, AY313209, AY309712, AY309578, AY309602, AY309778; Shaw 9855; DUKE. Takakia lepidozioides S. Hatt. \& H. Inoue; SB473; AF306950, AY312947, AY312921, AJ269686, AF197061, GQ368598, AY312936, AY312889, AJ309978, GQ368624; Schofield 86563; DUKE. Tetraphis pellucida Hedw.; MDP474; AY908021, AF231908, —, U18527, AF226033, GQ368596, U87091, AY908812, —, GQ368619; Risk \& Gross 105858; DUKE. Tetraplodon mnioides (Sw. ex Hedw.) Bruch \& Schimp.; L3; AF023804, AF023730, AY312922, AF023691, 一, GQ368595, AY312937, —, AY330474, GQ368618; Soderstrom s.n.; RNG. Timmia megapolitana Hedw.; BG1003; AF222902, AY312948, AY312923, AY330423, AY330452, GQ368597, AY312938, AY312890, AY330475, GQ368616; Schofield 97957; DUKE. 